Pontifícia Universidade Católica do Rio de Janeiro

A Percepção do Torcedor Carioca em Relação às Sociedades Anônimas no Futebol

Gabriel Stawnitzer Cardia

Trabalho de Conclusão de Curso

Centro de Ciências Socials - CCS Departamento de AdMinistração

Graduação em Administração de Empresas 
Gabriel Stawnitzer Cardia

\section{A Percepção do Torcedor Carioca em Relação às Sociedades Anônimas no Futebol}

Trabalho de Conclusão de Curso

Trabalho de Conclusão de Curso, apresentado ao programa de graduação em Administração da PUC-Rio como requisito parcial para a obtenção do título de graduação em Administração.

Orientador: Daniel Kamlot

Rio de Janeiro, novembro de 2019. 
"O conhecimento do Brasil passa pelo futebol" José Lins do Rego Cavalcante (escritor brasileiro). 


\section{Agradecimentos}

Aos meus pais, Eduardo e Monica, e à minha família, pela ajuda e suporte ao longo da minha vida. Aos meus amigos, em especial Pedro Henrique e Victor Paulo, e aos professores da Pontifícia Universidade Católica do Rio de Janeiro, em especial Sylvia e Martim, pelo apoio ao longo do curso. E ao meu orientador, Daniel, por toda dedicação e auxílio na elaboração deste trabalho. 


\section{Resumo}

\section{Cardia, Gabriel. A Percepção do Torcedor Carioca em Relação às Sociedades} Anônimas no Futebol. Rio de Janeiro, 2019. 49 p. Trabalho de Conclusão de Curso - Departamento de Administração. Pontifícia Universidade Católica do Rio de Janeiro.

Este trabalho foi realizado com o intuito de identificar a opinião dos torcedores dos quatro grandes clubes de futebol do Rio de Janeiro - Botafogo F.R., C.R. Flamengo, Fluminense F.C. e C.R. Vasco da Gama - em relação a uma possível mudança estrutural do mesmo, trocando o modelo de associação pelo tão falado modelo empresarial, se tornando uma sociedade anônima. Foram estudados diversos conceitos de marketing para a análise da relevância de fatores como marca, identidade e tradição dos clubes. Foi realizada uma pesquisa de campo utilizando questionários como meio de coleta de dados. Os resultados obtidos indicam a percepção do torcedor em relação ao modelo empresarial dos clubes, avaliando diferentes cenários, de manutenção e alteração da identidade da instituição.

\section{Palavras chave:}

Brand equity, clube-empresa, comportamento do consumidor, esporte, futebol, marketing, percepção, sociedade anônima, torcedor. 


\section{Abstract}

\section{Cardia, Gabriel. The Perception of Carioca Supporter's in Relation to Joint-Stock}

Companies in Soccer. Rio de Janeiro, 2019. 49 p. Course Conclusion Paper Department of Administration. Pontifical Catholic University of Rio de Janeiro.

This paper was carried out with the purpose of identify the opinion of the fans of the four major soccer clubs of Rio de Janeiro - Botafogo F.R., C.R. Flamengo, Fluminense F.C. and C.R. Vasco da Gama - regarding a possible structural change of the association model by the so-called joint-stock model, becoming a corporation. Several marketing concepts were studied to analyze the relevance of factors such as brand, identity and club tradition. A field research was conducted using questionnaires as a means of data collection. The obtained results indicate the perception of the fan in relation to the business model of the clubs, evaluating different scenarios, of maintenance and alteration of the identity of the institution.

\section{Key words:}

Brand equity, consumer behavior, corporate club, fan, marketing, perception, soccer, sport. 


\section{Sumário}

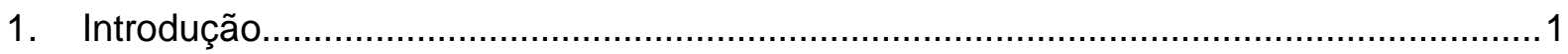

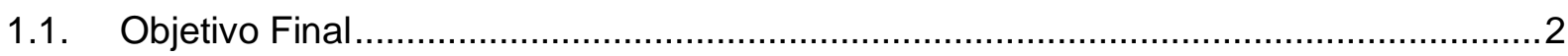

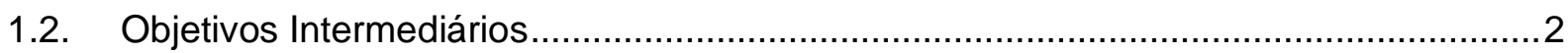

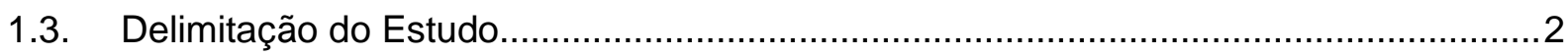

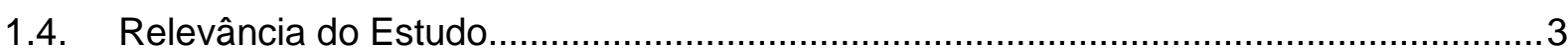

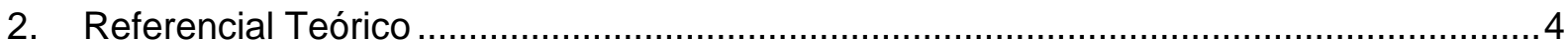

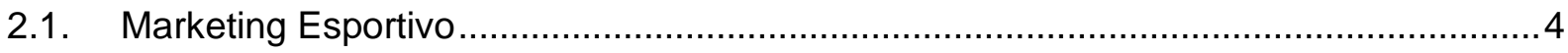

2.2. Percepção e Comportamento do Consumidor ............................................................

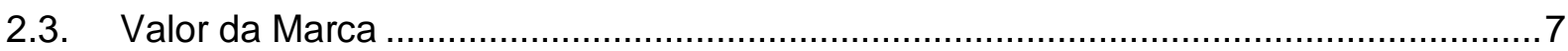

2.4. Identidade e Atributos da Marca ...........................................................................10

2.5. Sociedades Anônimas .........................................................................................12

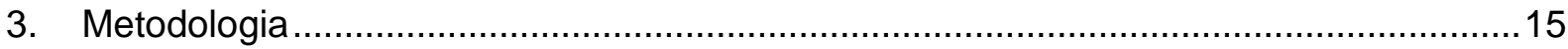

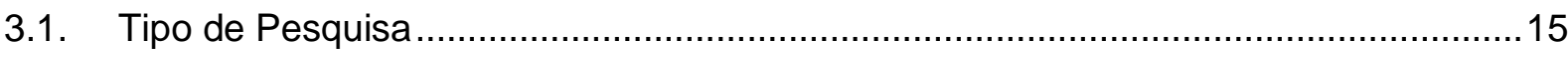

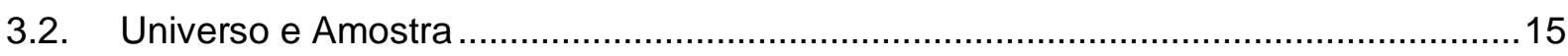

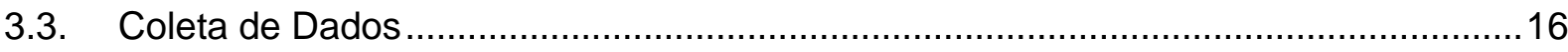

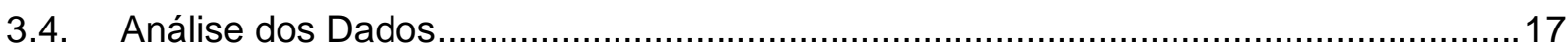

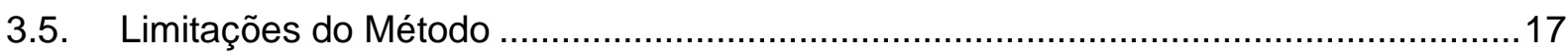

4. Análise de Resultados .......................................................................................

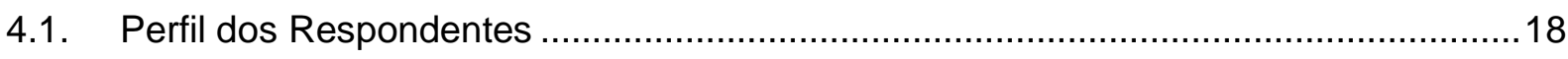

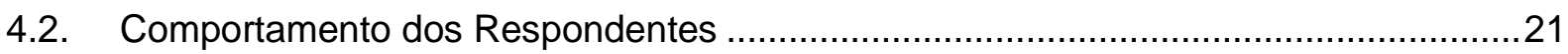

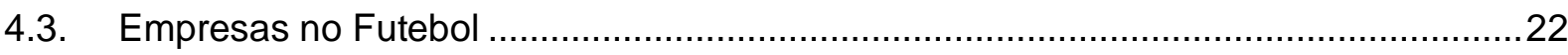

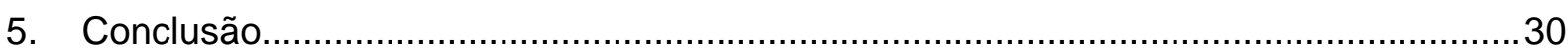

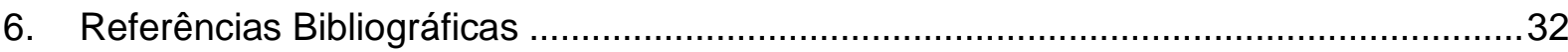

Anexo 


\section{Lista de figuras}

Figura 1: Pirâmide de brand equity .9

\section{Lista de tabelas}

Tabela 1: Opinião dos respondentes em relação a aspectos de uma possível mudança .....29

\section{Lista de gráficos}

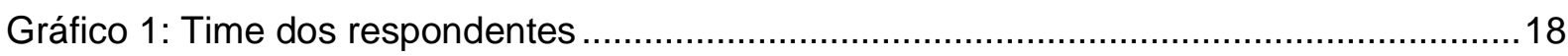

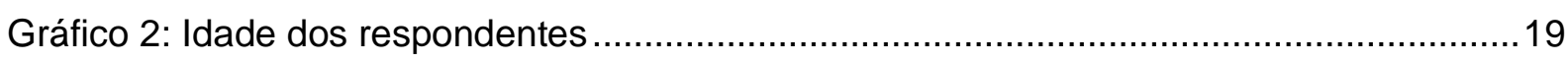

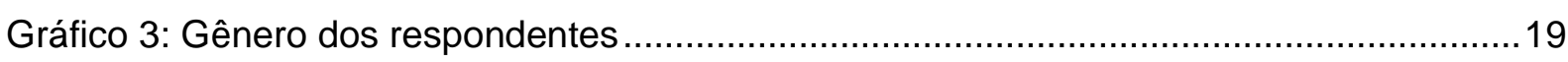

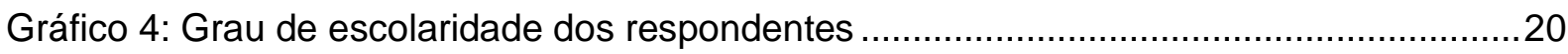

Gráfico 5: Renda familiar mensal dos respondentes.....................................................21

Gráfico 6: Comportamento do respondente em relação ao clube .......................................22

Gráfico 7: Opinião em relação à ideia de investidores comprarem clubes ............................23

Gráfico 8: Opinião dos torcedores em relação à ideia de compra dos clubes.......................23

Gráfico 9: Opinião dos respondentes em relação à ideia de investir em um clube ................24

Gráfico 10: Opinião dos respondentes em relação à possibilidade de ajudar seu clube

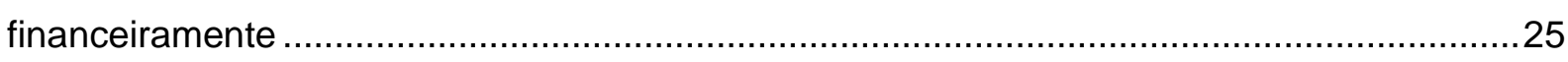

Gráfico 11: Percepção do torcedor em relação aos resultados de uma possível mudança ..26

Gráfico 12: Opinião dos torcedores em relação à mudança institucional dos clubes 27

Gráfico 13: Opinião dos torcedores em relação à transformação com alteração da identidade dos clubes. 


\section{Introdução}

O mundo do futebol é complexo. Os torcedores são movidos pela paixão, e não pela razão. Muitos fazem coisas que jamais fariam em outras circunstâncias, tudo pelo seu time do coração. Torcedores viajam milhares de quilômetros apenas para ver um jogo de noventa minutos e voltar para casa. Gastam muito dinheiro com programas de sócio torcedor que muitas vezes não lhes dão nenhum benefício (financeiro ou esportivo) em retorno. Tudo isso é feito por amor ao clube.

Hoje em dia é tendência se falar em clubes empresas e sociedades anônimas, as S.As, no meio do futebol, especialmente no futebol brasileiro (como já comentado publicamente pelo presidente do Club Athletico Paranaense ${ }^{1}$, Mario Celso Petraglia (RUDNICK, 2019) e percebido na compra do Red Bull Bragantino² pela Red Bull Brasil (ESTADÃO, 2019)). Com clubes extremamente endividados, somando $R \$$ 6,9 bilhões em dívidas (LANCE!, 2019), muitos veem tal transformação como a única solução para elevar novamente o patamar do futebol nacional e adequar o mesmo a algo que já é padrão no futebol europeu.

Porém, muitos dos clubes brasileiros, especialmente os grandes, ainda têm receios em relação a essa hipótese. Ademais, seus estatutos, nos moldes atuais, não permitem tal alteração na estrutura. Porém, qual seria a reação do torcedor brasileiro a "privatização", à transformação, de seu clube em um "clube de empresário"? O torcedor ainda apoiará este clube? Já houve exemplos pelo mundo de cenários completamente distintos, torcedores de diferentes clubes tiveram reações totalmente diferentes a tal transformação e mudanças feitas pelo novo dono na história da instituição. Casos distintos podem ser vistos, por exemplo, no Operário, do Mato Grosso do Sul, que, após ser adquirido por um grupo, viu o Novoperário surgir, um clube fundado por torcedores do primeiro, que, insatisfeitos com a gestão, criaram um novo rival. Por outro lado, se tem o próprio Bragantino, que segue com o apoio de sua torcida mesmo após uma mudança de nome.

Porém, isso seria algo inédito para qualquer clube considerado grande no país, tendo em vista o ranking da Confederação Brasileira de Futebol (CBF). Atualmente, possuem algum

\footnotetext{
1 Antigo Clube Atlético Paranaense, renomeado no final do ano de 2018, em um processo de rebranding, um processo de reposicionamento e atualização da marca.

2 Antigo Clube Atlético Bragantino, renomeado quando comprado pela empresa austríaca, em abril de 2019.
} 
tipo de bloqueio em seus estatutos. Todavia, o cenário futuro parece ser diferente. Como seria a reação do torcedor à eventual transformação mencionada?

\subsection{Objetivo Final}

O presente trabalho tem como objetivo final analisar as opiniões e impressões do torcedor em relação a uma potencial "privatização", isto é, à transformação do seu clube em uma sociedade anônima.

\subsection{Objetivos Intermediários}

Para alcançar o objetivo final proposto, tem-se como objetivos intermediários:

1. Identificar a opinião do torcedor em relação à transformação citada;

2. Analisar a atitude do torcedor em relação a uma eventual compra do clube num cenário de manutenção dos atributos do mesmo;

3. Analisar a atitude do torcedor em relação a uma eventual compra do clube num cenário de alteração dos atributos do mesmo.

\subsection{Delimitação do Estudo}

O estudo será delimitado aos torcedores jovens (de 18 a 31 anos) cariocas dos quatro grandes clubes do Estado do Rio de Janeiro: Botafogo de Futebol e Regatas; Clube de Regatas do Flamengo; Clube de Regatas Vasco da Gama e; Fluminense Football Club. O mesmo também será delimitado ao ano de 2019 e desconsiderará fatores financeiros, torcidas organizadas e classificação em campeonatos, focando apenas no modelo de gestão das instituições citadas. 


\subsection{Relevância do Estudo}

O futebol é um campo de relevância no mundo, sendo uma das indústrias que mais movimentam dinheiro. Em 2017, os maiores clubes brasileiros tiveram faturamento de 5,05 bilhões de reais, o que demonstra um crescimento de 57,25\% em sete anos, de 2012 a 2019 (CERIONI, 2018). Assim, percebe-se que o futebol movimenta muito dinheiro e, embora o Brasil ainda esteja bem atrás do futebol europeu em termos de receitas financeiras, que faturou 100 bilhões de reais na temporada 2016-17 (CHADE, 2018), o mesmo ainda é bastante relevante em termos de volume.

Voltando para o futebol brasileiro, do valor citado, os quatro grandes do Rio de Janeiro são responsáveis por 1,33 bilhão de reais, representando $26,38 \%$ do total do país, ficando atrás apenas do Estado de São Paulo, que é responsável por 34,26\% do total (CERIONI, 2018), algo que pode ser explicado pelo fato de que o estado é o centro econômico do país. Ademais, vale destacar que São Paulo também possui uma população maior que o Rio de Janeiro, o que também influencia o número citado.

Mesmo com valores menores, o futebol brasileiro é tratado com muita importância no mundo. O holandês Clarence Seedorf (2012), ex-jogador do A.F.C. Ajax, U.C. Sampdoria, Real Madrid C.F., F.C. Internazionale M., A.C. Milan e Botafogo F.R. afirmou, por meio de carta aberta, que jogaria na "meca do futebol" ao concretizar sua ida para o alvinegro carioca. Ademais, o Brasil é o único país que participou de todas as 21 Copas do Mundo da FIFA (Fédération Internationale de Football Association, em francês, ou, Federação Internacional de Futebol) e é o maior campeão do torneio, com cinco títulos. Em relação ao Rio de Janeiro, o Estado é local de quatro dos maiores clubes do país e é local do Estádio Jornalista Mário Filho, o Maracanã, que já foi o maior estádio do mundo, dentre outros fatos.

Assim, comprovando que o futebol é um mercado importante mundialmente e que o Brasil e, mais especificamente, o Estado do Rio de Janeiro, são importantes em tal mercado, é de suma importância compreender a percepção e o comportamento do torcedor carioca em relação aos elementos que são responsáveis por tal movimentação financeira, tal história e tradição, etc.: os clubes. 


\section{Referencial Teórico}

\subsection{Marketing Esportivo}

Marketing esportivo é uma subcategoria do marketing, que, por vez, é a administração dos relacionamentos com o cliente. Sendo assim, os objetivos do marketing são: atração de clientes; geração de valor e; manutenção dos clientes (KOTLER e ARMSTRONG, 2008). Marketing, etimologicamente, é uma palavra em inglês, que tem como origem o verbo "to market', isto é, com sentido de "negociar em mercado" (SOBRAL e PECI, 2013).

Segundo a American Marketing Association (AMA, 2013), marketing é uma atividade que contém instituições e processos, que visam criar, comunicar, entregar e trocar ofertas, as quais possuem valor agregado na visão dos consumidores.

De acordo com o The Chartered Institute of Marketing (CIM, 2015), o mesmo pode ser descrito como um processo de gerenciamento, que tem como objetivo primário a identificação, antecipação e satisfação nas necessidades do consumidor, visando o lucro. Tal definição destaca um termo importante no cenário global atual, o lucro, que, por vez, é o objetivo principal de quase todas empresas que operam no globo, salve algumas exceções, como ONGs (organizações não governamentais), fundações etc. $O$ termo também tem destaque de Kotler e Keller (2012), que afirmam que o marketing busca suprir as necessidades, gerando lucro.

O marketing também pode ser definido como um processo, voltado para o planejamento e execução do mix de marketing, os "4P's", isto é, decisões sobre preço, produto, promoção e ponto de venda/praça (SOBRAL e PECI, 2013).

Tendo o conceito de marketing em vista, pode-se discutir a respeito de marketing esportivo, que é a aplicação dos conceitos e princípios de marketing na indústria esportiva. Trata-se de um conjunto de conceitos globais de marketing, aplicados à prática e, em uma visão mais promocional, à divulgação de modalidades, instituições e eventos esportivos (BERTOLDO, 2000). Os objetivos do marketing esportivo são os mesmos do marketing de forma geral, porém, quando no marketing se diz "empresa", no marketing esportivo pode-se, além de empresa, fazer referência a instituições esportivas, tais como clubes, associações, federações, ligas, atletas, dentre outros. 
Assim como o marketing, de forma geral, o marketing esportivo também faz uso do mix de marketing. No caso, o produto são os jogos, eventos, competições, ligas, atletas etc., o preço diz respeito não somente aos ingressos, mas também às transmissões, direitos (de imagem, federativos, econômicos etc.), dentre outros. Por vez, a promoção está vinculada a elementos como publicidade e patrocínio. E, por fim, o ponto de venda diz respeito à distribuição esportiva, que pode ser realizada dentro das arenas, via transmissão ou até mesmo por eventos complementares (MULLIN, HARDY e SUTTON, 2004).

Vale destacar que o marketing esportivo não está necessariamente ligado ao evento esportivo, como, por exemplo, uma partida de futebol. O mesmo pode estar vinculado a elementos do esporte, como a venda de bolas de basquete, tacos de beisebol, discos de hóquei, dentre outros.

Outro ponto importante é a utilização do esporte como canal para o marketing. Não há a obrigação de utilização de produtos esportivos no meio. Um exemplo é o Super Bowl, o campeonato anual de futebol americano dos Estados Unidos. O evento se tornou tão grande que empresas dos mais variados setores (tais como Google (tecnologia), Pepsi (bebidas), Toyota (automóveis), Pampers (fraldas), Bubly (águas gaseificadas), Colgate (cremes dentais), dentre outros) utilizam o evento como meio de propaganda. $\mathrm{E}$ a organização do mesmo compreende o valor agregado do torneio. Um exemplo é o Super Bowl LIII (2019), cujo minuto de comercial custou 5,25 milhões de dólares, representando um aumento de $775 \%$ em relação ao Super Bowl I (1967), considerando valores ajustados pela inflação (SCHWARTZ, 2019; SUNERSON, 2019). O fato de as empresas estarem dispostas a pagar tal valor demonstra que as mesmas acreditam no potencial do comercial transmitido em tal meio esportivo, devido a sua audiência e perfil dos telespectadores, o que é um resultado justamente do marketing esportivo aplicado ao evento.

Sendo assim, o marketing esportivo é a aplicação do marketing no esporte, com suas devidas adaptações (PITTS e STOTLAR, 2002).

O marketing esportivo é o processo de elaboração e implementação das atividades do marketing, tais como produção, formatação de preço, promoção e distribuição, os “4P's", a um produto esportivo (PITTS e STOTLAR, 2002).

Assim, o marketing esportivo é um conjunto composto pelo marketing do esporte e o marketing através do esporte (como o exemplo citado previamente), no qual o primeiro faz referência ao marketing desenvolvido nas instituições esportivas e, o segundo, ao uso do esporte como veículo de mídia - em uma conotação mais publicitária (CONTURSI, 1996). 
De forma geral, o marketing esportivo, assim como o marketing "tradicional", busca gerar oportunidades de negócio, isto é, explorar meios de gerar valor, satisfazer o cliente. Porém, no meio esportivo, por meio do canal conhecido como esporte. Sendo assim, o marketing esportivo é aquele que utiliza o esporte como ferramenta onde se adotam estratégias de marketing.

\subsection{Percepção e Comportamento do Consumidor}

Comportamento do consumidor é a forma pela qual um indivíduo se comporta em relação ao consumo (SCHIFFMAN e KANUK, 2000). É o processo de seleção, compra, uso e descarte de produtos e/ou serviços, que estão relacionados às suas necessidades e/ou desejos (SOLOMON, 2016). São as atividades realizadas por tais indivíduos em relação ao consumo de tais produtos e/ou serviços (ENGEL, BLACKWELL e MINIARD, 2011).

Segundo Engel, Blackwell e Miniard (2011), para que seja possível compreender os consumidores, é necessário não apenas analisá-los, mas também analisar o ambiente no qual o mesmo se encontra. Isto com o intuito de identificar os possíveis fatores que possam influenciar a decisão de compra de tal público alvo. Tal análise engloba possíveis tendências, grupos de influência, motivações, atitudes, estilo de vida a padrões de consumo.

Seguindo tal linha de pensamento, para compreender as necessidades dos indivíduos é necessário analisar não somente o indivíduo como entidade única, mas também grupos e organizações relacionados e como os mesmos se comportam (KOTLER e KELLER, 2012).

Vale destacar que com o crescente número de opções no mercado, tal fator se torna cada vez mais relevante. Em um mercado escasso, o mesmo pode não ser um fator crucial, devido às poucas opções. Porém, como atualmente quase todos os mercados tendem a ser saturados, a compreensão do público é fator decisivo para a atração do mesmo, algo que se relaciona diretamente ao conceito de marketing, apresentado previamente.

Entender o comportamento do consumidor tem como objetivo tornar possível a melhoria do composto de marketing, isto é, os produtos e serviços oferecidos, o ponto de venda de melhor acesso, definição de preço (e condições de troca) e otimização do método de promoção, além de compreender as motivações por trás do fator de decisão do consumidor.

Já em relação à percepção, do latim perceptĭo, esta refere-se à ação de perceber, por meio de estímulos, imagens, impressões etc. A percepção, no meio psicológico, é a recepção, 
elaboração e interpretação da informação obtida por meio dos estímulos. É o primeiro processo de captação de informação (KOTLER e KELLER, 2012).

A percepção é um processo dinâmico, no qual os indivíduos selecionam e interpretam informações para criar uma "visão" do ambiente, o qual emite estímulos que influenciam a mesma. Ademais, a percepção é única e individual, ou seja, cada indivíduo possui sua própria percepção única sobre cada tópico (KOTLER e KELLER, 2012).

A percepção também pode ser definida como a forma do indivíduo captar o ambiente à sua volta. Sendo assim, dois indivíduos podem ser expostos aos mesmos estímulos e ao mesmo ambiente, porém, suas percepções do redor podem ser distintas, pois remetem à forma de cada um observar o mesmo. Desta forma, a percepção é um processo no qual o indivíduo interpreta estímulos visando a algum significado no ambiente. Por vez, um estímulo é uma unidade de dados para algum sentido. Ou seja, estímulos podem remeter a marcas, anúncios, embalagens, dentre outros (SCHIFFMAN e KANUK, 2000). Ademais, vale destacar que tais estímulos não são necessariamente explícitos, podendo ser subliminares, isto é, estímulos abaixo do nível de consciência do indivíduo (SCHIFFMAN e KANUK, 2000).

Vale destacar também que os estímulos emitidos por elementos do ambiente são inúmeros e, consequentemente, não é viável ou possível absorver todos. Sendo assim, existe o fator "atenção". A atenção determina quais estímulos são absorvidos pelo indivíduo. É a sua capacidade de processá-los, de focar em algo. A descrição representa o processo perceptivo, que, por vez, é o recebimento de tais estímulos (de forma visual, sonora etc.) seguido pela atenção e interpretação dos mesmos. Assim, a interpretação é o significado dado a algo, o conteúdo absorvido, o entendimento do estímulo absorvido (SOLOMON, 2016).

Tendo esclarecido o conceito de estímulo, têm-se os impulsos, que são um tipo de estímulo. Impulsos requerem ações, no caso, por parte do consumidor. O impulso é formado por sugestões, que também são estímulos de menor força. Tais sugestões estão à volta do cliente, no ambiente. São as mesmas que determinam quando e como o consumidor irá responder. Com o alinhamento e direcionamento de tais estímulos ao cliente, a probabilidade de resposta tende a subir e, consequentemente, aumenta a probabilidade de sucesso de venda (BRANDÃO, 2009).

\subsection{Valor da Marca}

O valor, em um termo amplo, se divide em valor de um produto/serviço e valor de marca. O valor de um produto ou serviço é referente ao retorno oferecido ao cliente na compra 
(e/ou consumo) de tal item. O mesmo está diretamente relacionado à expectativa do cliente em relação ao tal produto ou serviço, o que significa que o quão maior for a expectativa do mesmo, mais difícil será superá-la, e, consequentemente, agradar o cliente. Por tal motivo, a definição de tais expectativas é elemento de extrema cautela. No caso da definição de expectativa baixa demais, será fácil superá-las, porém o item ofertado poderá não atrair clientes suficientes perante outras opções no mercado. Em contrapartida, no cenário oposto, de expectativa muito elevada, a possibilidade de insatisfação é alta (KOTLER e ARMSTRONG, 2008).

O valor de marca é um dos diferenciais mais importantes entre os produtos e serviços disponíveis no mercado (com devidas exceções, vide commodities). Dois produtos podem ofertar o mesmo benefício, e, neste caso, o cliente escolherá o desejado com base no valor agregado, que pode incluir diversos fatores, tais como benefícios complementares, preço, praticidade, velocidade de entrega, dentre outros. Assim, valor é um conceito central do marketing e é a relação de comparação entre os benefícios tangíveis e intangíveis aos custos financeiros e psicológicos no processo de aquisição do mesmo. De forma simples, o valor de marca está ligado à satisfação e pode ser interpretado como uma combinação de qualidade, serviço e preço (QSP), que é denominada "tríade do valor para o cliente" (KOTLER e KELLER, 2012).

Tendo tal conceito definido, deve-se compreender o que é uma marca. A definição de uma marca é uma forma de diferenciar os produtos e serviços de diferentes empresas. Marca, ou brand (em inglês), vem do nórdico brandr, que significa "queimar", pois proprietários de gado utilizavam marcas de fogo para identificar seus animais (KELLER e MACHADO, 2006).

Segundo a AMA (2013), "marca é um nome, termo, design, símbolo, ou qualquer outra característica que identifique um bem ou serviço de um enquanto o diferencia de outros". Ainda de acordo com a associação, a marca é um compilado de ideias que representem a experiência de um grupo de consumidores. Sendo assim, uma marca remete a uma cultura, um estilo de vida. Marca é uma identidade.

Por sua vez, o valor de marca, ou brand equity (em inglês), é construído com base no valor agregado de seus produtos e serviços. Tendo em vista que o produto ou serviço é o meio de contato da marca com seu público alvo, o mesmo é o meio de entrega dos benefícios ofertados da empresa. Segundo a AMA (2013), o brand equityé o conjunto de consequências, perante a visão do consumidor, das atitudes de uma marca. É o seu nível de conhecimento, com base na ideia de que tal marca consegue gerar mais receita de seus produtos do que a concorrência, devido ao maior valor agregado atribuído pelo nome da mesma do que um produto similar de uma concorrente, que possua um valor de marca inferior. 
Portanto, o valor de uma marca está relacionado à sua força. O valor da marca é um conjunto de atributos e potenciais fraquezas ligados ao nome da mesma. A medição de tal valor é delimitada por quatro categorias principais: percepção de marca; lealdade de marca; qualidade percebida; e associações de marca (AAKER, 1996).

O valor de marca está ligado a elementos que são expostos na pirâmide de brand equity. Tal pirâmide classifica, em níveis, conforme demonstrado na Figura 1, os seguintes tópicos, de baixo para cima, respectivamente: proeminência; desempenho e imagem; julgamento e sensações; e ressonância. Tendo isso em mente, tais tópicos estão ligados, respectivamente, a: identidade de marca (descrito no tópico 2.4); significado de tal identidade; resposta; e relacionamentos. Sendo assim, os objetivos da marca em tais estágios são, respectivamente, de: relacionamento profundo e amplo da marca; pontos de paridade e diferença; reações positivas e acessíveis; e fidelidade intensa e ativa (KOTLER e KELLER, 2013; AAKER, 1991).

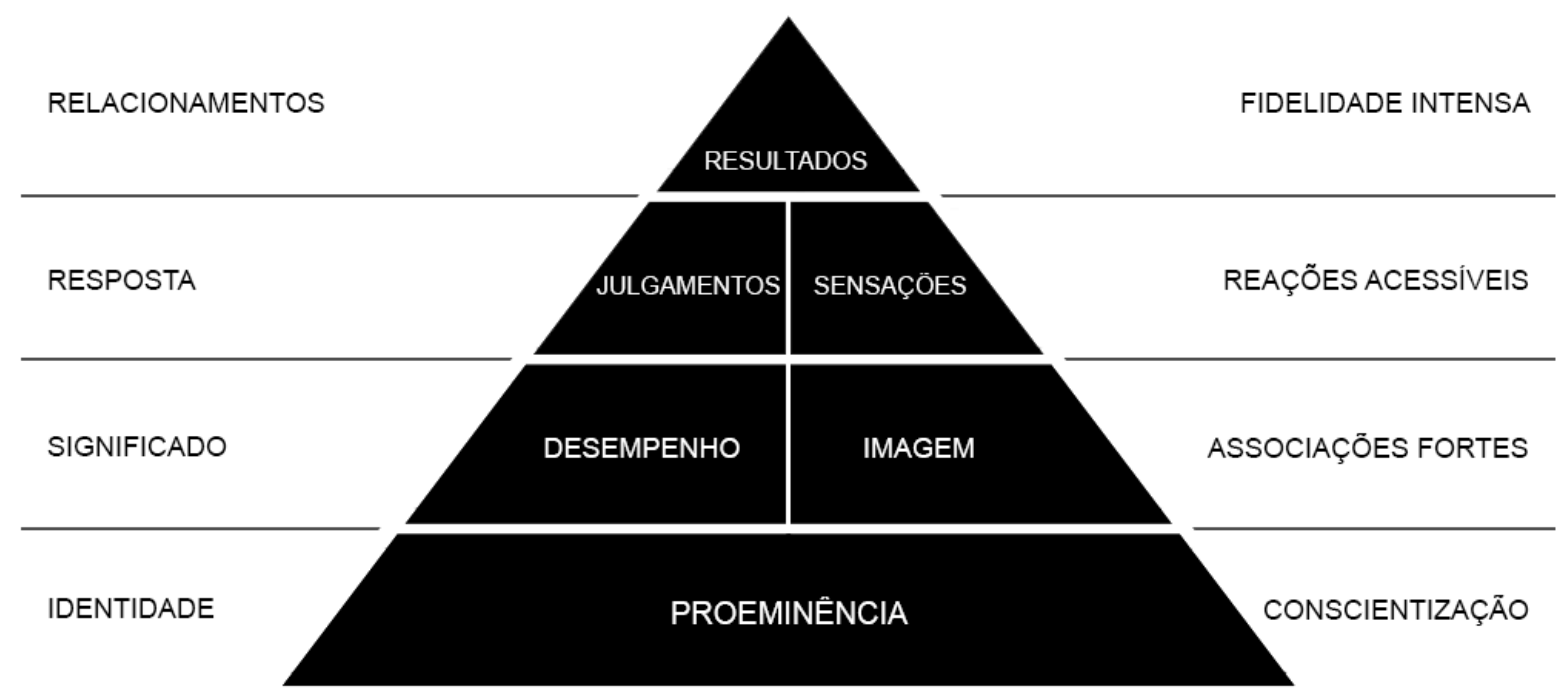

Figura 1: Pirâmide de brand equity

Fonte: Adaptado pelo autor com dados de Kotler e Keller (2013).

O brand equity, segundo Kohli e Leuthesser (2001), é o fator diferencial na resposta do consumidor aos estímulos absorvidos. Ademais, o brand equity é um efeito comercial, que, por vez, é unicamente atribuído à marca (KELLER, 1993). De tal forma, a marca impõe determinado valor a seus produtos e/ou serviços. E tal valor é determinante na ação do consumidor, dependendo de sua categoria e perfil de seu público, é o fator que determina a compra de tal produto perante outros disponíveis no mercado, fornecidos por concorrentes. 
O escritor Stephen King (apud AAKER, 1991, p. 16), em evento no WPP Group (empresa multinacional britânica de publicidade e relações públicas), em Londres, falou:

\footnotetext{
"Um produto é algo que é construído em uma fábrica; uma marca é algo que é comprado por um consumidor. Um produto pode ser copiado por um concorrente; uma marca é única. Um produto pode ser rapidamente ultrapassado; uma marca de sucesso é eterna."
}

Tal frase serve como demonstração da importância do valor da marca e percepção do consumidor perante a mesma.

Por fim, o valor de uma marca pode ser contabilizado de maneira quantitativa, como, por exemplo, em valor monetário. Outra demonstração do valor e força das marcas se dá pela dificuldade de estabelecê-las e por quanto outras empresas estão dispostas a pagar para obtê-las (AAKER, 1991). Um exemplo de tal situação foi a compra do clube inglês Chelsea Football Club, em 2003, pelo russo-israelense Roman Abramovich, por 140 milhões de libras esterlinas (cerca de 767 milhões de reais). A compra demonstra que o empresário avaliou o clube em tal valor, tendo em vista seus ativos, tangíveis, tais como edificações, e intangíveis, como sua marca. O mesmo também acredita que o valor da marca Chelsea F.C. cresceu em sua gestão, tendo em vista sua afirmação, em 2018, de que iria demandar uma oferta de ao menos 2,5 bilhões de libras esterlinas (cerca de 13,7 bilhões de reais) para cogitar vender o clube (HUGHES, 2018) ${ }^{3}$.

\subsection{Identidade e Atributos da Marca}

Tendo em vista a definição de marca (tópico 2), sabe-se que a mesma possui diversos elementos que a compõem. Assim, como já citado em tal tópico, a marca utiliza diversos elementos para identificar-se e diferenciar-se perante outras. Tal utilização, somada à sua cultura organizacional, valores da instituição, visão e missão, formam sua identidade. Sendo assim, a identidade de uma marca é um veículo que transmite a formação de sua imagem à comunidade é como a mesma é representada. A identidade de uma marca remete à sua essência e individualidade (KOTLER e KELLER, 2012; AAKER, 1996).

\footnotetext{
${ }^{3}$ Conversões de moeda utilizando a taxa de 1 GBP para 5,48 BRL, segundo cotação no dia 30 de
} novembro de 2019. 
A identidade de uma marca é o conjunto de seus ativos e passivos, ligados ao seu nome e seus símbolos. É a soma (ou subtração) de valor que se agrega a um serviço e/ou produto (AAKER, 1996).

Sendo assim, a identidade de uma marca é composta por atributos. Tais atributos são a composição da marca, citado previamente no tópico 2.3. A identidade de marca é um conjunto exclusivo de elementos e associações que representam uma promessa ao público (AAKER, 1991; AAKER, 1996).

A identidade de marca é a descrição da marca, por meio de seus atributos e elementos, tangíveis e intangíveis, que a promovem em um mercado. Sendo assim, a identidade de uma marca está ligada diretamente à sua força e reputação. Uma marca sem uma identidade única e exclusiva tende a não possuir uma força e reputação relevantes no mercado, pois não se diferencia das concorrentes, sendo força, em tal contexto, uma diferenciação potencial, e relevância e reputação, estima e conhecimento da marca (KOTLER e KELLER, 2012).

A identidade de uma marca, que pode conter elementos tangíveis (como a clássica garrafa de vidro da Coca-Cola ou o ornamento do logo da Mercedes-Benz nos capôs de seus carros, por exemplo) e intangíveis (como a cultura organizacional do Google), foca no reconhecimento, na visibilidade, na diferenciação, etc. A ideia da identidade de uma marca é representar suas visões ao público, torná-la visível, única e acessível (WHEELER, 2018).

O conceito de identidade de marca muitas vezes se mistura ao design, tendo em vista que o mesmo é o responsável pela representação da marca em muitos dos casos. Citando Moira Cullen (apud WHEELHER, 2018, p. 4), ex-vice-presidente global de design da PepsiCo Inc.: "design diferencia e incorpora os intangíveis - emoção, contexto e essência - que mais importam para os consumidores".

A identidade de uma marca é sua representação na arena competitiva, é confeccionada com base no mix de marketing e busca expor sua cultura para o ambiente externo. Seu sucesso demonstra sua força, a lealdade de seus consumidores e o valor da marca por trás de tal identidade.

Ademais, como já dito, a mesma é a base do valor da mesma, sendo a base da pirâmide de brand equity. Sendo assim, a identidade da marca é a forma de expressão da mesma na busca de valor agregado, é a maneira de se diferenciar, se destacar, ganhar enfoque no mercado perante as concorrentes, por meio da exposição de seus ideais. É a transposição da visão da instituição.

Aaker (1996) afirma que a construção de uma marca se dá por três etapas: análise estratégica da marca; definição do sistema de identidade da marca; e implementação da 
identidade da marca. A primeira se dá pela análise dos consumidores, da concorrência e própria. A segunda, pela identidade nuclear (a identidade central, atemporal e constante, que integra seus valores, fundamentos e competências, é o que a marca representa, é sua alma) e extensa (elementos que lhe fornecem textura e suporte, são mutáveis à mudanças no ambiente, organizada em torno da anterior, incluem detalhes que auxiliam a visualização da representação da anterior), além de considerações a respeito da proposição de valor, credibilidade e relacionamento. Por fim, a terceira remete à determinação de posicionamento - que se dá em dois estágios -, programas de comunicação e avaliação dos resultados.

Sendo assim, percebe-se que a identidade de uma marca se dá por diversos fatores que, por vez, cercam a mesma. Uma marca é uma representação de um ideal, uma visão. Por fim, Aaker (1996, p. 68) também afirma que:

\footnotetext{
"A identidade da marca consiste num conjunto único de associações, que as estratégias pretendem criar ou manter. Essas associações constituem o que a marca representa e integram uma promessa aos consumidores, por parte dos membros da organização."”
}

\subsection{Sociedades Anônimas}

As sociedades anônimas são regulamentadas no Brasil pela Lei 6.404, de 15 de dezembro de 1976, conhecida como "Lei das Sociedades por Ações". Segundo tal lei, sociedades anônimas são empresas que obrigatoriamente possuem capital dividido em ações e responsabilidade dos sócios ou acionistas limitada ao preço de emissão das ações subscritas ou adquiridas (artigo $1^{\circ}$ ).

Em relação ao objeto social, pode ser objeto da companhia qualquer empresa, desde que a mesma possua fim lucrativo e não detenha caráter contrário à lei ou à ordem pública. Sendo assim, qualquer que seja o objeto, que é definido de acordo com o estatuto social da mesma, a sociedade é mercantil e se rege perante as leis e usos do comércio (artigo $2^{\circ}$ ).

Frisa-se que, independentemente de seu objeto, a sociedade anônima é uma sociedade empresária, isto é, uma na qual os sócios possuem responsabilidade solidária, que, por vez, é a permissão de cobrança de determinada obrigação a qualquer um dos sócios legalmente responsáveis. Destaca-se que o capital dos sócios não é atrelado ao capital da sociedade formada, dado o princípio da entidade (artigo 982, parágrafo único). Porém, conforme mencionado previamente, 0 artigo $1^{\circ}$ delimita tal responsabilidade ao preço de emissão das ações dos mesmos. 
Vale destacar que a denominação da empresa deve ser acompanhada das expressões "companhia" ou "sociedade anônima" (artigo $3^{\circ}$ ).

Segundo o artigo $4^{\circ}$ da lei, a companhia pode ser determinada como aberta ou fechada. No caso de companhias abertas, os valores imobiliários de sua emissão são admitidos à negociação no mercado de valores imobiliários (artigo 40). Isto é, para tal, a sociedade deve estar registrada na Comissão de Valores Mobiliários (CVM).

Além de ações, tais sociedades também podem negociar valores mobiliários por meio de debêntures.

Em casos de companhias fechadas, as mesmas podem comercializar suas ações somente de forma privada, sendo assim, não é permitida a veiculação de anúncios públicos para a operação. A mesma também não possui requerimento de registro no órgão competente citado.

Assim sendo, uma sociedade anônima pode ser categorizada como "sociedade anônima de capital aberto" ou "sociedade anônima de capital fechado".

Outro requerimento da Lei refere-se à estrutura organizacional das sociedades citadas. As mesmas devem, obrigatoriamente, ser compostas por uma assembleia geral, um conselho de administração (não requerido para companhias fechadas), diretoria e conselho fiscal. Ademais, é necessário um estatuto social, que pode determinar mais obrigações à empresa, de forma individual.

Também vale destacar que as sociedades anônimas são normalmente constituídas por uma assembleia geral, um conselho de administração, um conselho fiscal e uma diretoria.

Vale destacar que a aplicação de sociedades anônimas no futebol brasileiro só é permitida devido à Lei 9.615, de 24 de março de 1998. A Seção IV de tal lei permite que instituições esportivas sejam (ou sejam controladas por) empresas privadas com fins lucrativos. É tal lei que possibilita a atuação da CBF visando o lucro.

Porém, mesmo com a mudança permitida por lei, muitos dos clubes considerados grandes no país têm bloqueios em seus respectivos estatutos contra tal mudança. Alguns clubes, como o Athletico Paranaense, já tiveram seus estatutos alterados para permitir o modelo. E outros, como o Botafogo, estão em processo de mudança, para poder viabilizar a criação de uma sociedade anônima para gerir o futebol do clube. Porém, a maior parte ainda não se movimentou para seguir em frente no processo (SANTANA, 2019).

Tendo em vista o ranking da CBF (2019), percebe-se que os cinquenta e cinco primeiros clubes não são empresas. O primeiro clube-empresa do ranking é o Tombense, de 
Minas Gerais, na quinquagésima sexta colocação. Porém, conforme já citado, Botafogo e Athletico Paranaense já estão em fases avançadas para se tornarem empresas, sendo que o primeiro já realizou até conversas com investidores para alavancar o poderio financeiro da instituição (SANTANA, 2019).

O modelo é visto como uma receita para o sucesso. Ao redor do mundo, é possível ver diversas empresas que adotaram o modelo de S.A.s e cresceram. Um exemplo é o F.C. Porto, de Portugal, que profissionalizou a gestão e tornou o clube um dos gigantes europeus. Criada em 1997, a empresa, que se encontra na bolsa de valores de Lisboa, possibilitou ao clube portuense se tornar a porta de entrada de diversos atletas sul-americanos na Europa, devido ao seu poder financeiro e política de investimentos (CAPELO, 2019). 


\section{Metodologia}

\subsection{Tipo de Pesquisa}

Segundo Vergara (2007), uma pesquisa pode ser definida de duas formas: quanto aos fins; e quanto aos meios. A primeira, que no presente caso é explicativa, diz respeito ao objetivo primário de transformar o estudo em dados justificados, isto é, obter o motivo da ação percebida. Já a segunda, que no presente caso é de campo, diz respeito aos meios de investigação, que é realizada no local de observação dos fenômenos. Neste estudo, o local é abrangente, tendo em vista que se trata da percepção do consumidor, que ocorre a todo momento, em qualquer lugar.

Assim, são realizadas análises, detalhadas mais a frente, para coletar dados que representem a opinião, percepção e impressões dos respondentes perante o tópico analisado e variações de cenários descritos.

\subsection{Universo e Amostra}

O universo, que é o grupo de maior abrangência, são os torcedores dos quatro grandes clubes da cidade do Rio de Janeiro, residentes da região. Tendo em vista a amostragem quantitativa com seleção realizada por meio do envio do questionário da pesquisa, destacase que a mesma não é probabilística. Em relação ao universo, nota-se que a população da capital carioca é de 6,72 milhões de habitantes (IBGE, 2019). Assim, segundo estudo do Instituto Informa, publicado no Globo (2014), se tem, para os quatro grandes clubes do estado, uma divisão na qual o rubro negro detém $50,4 \%$ da torcida local, o cruzmaltino segue em segundo no ranking com $18 \%$, seguido pelo tricolor, com $9,4 \%$ e pelo glorioso, com $7,7 \%$. Vale destacar que tal estudo contempla os percentuais para o estado, porém, como o mesmo possui o valor que mais se aproxima do desejado, o universo apresentado em tal trabalho irá utilizar tais resultados como fundamento para sua base de cálculo. Assim, tendo em vista que 
$85,5 \%$ dos habitantes da cidade do Rio de Janeiro torcem para algum dos quatro grandes clubes da região, se tem um universo de 5,75 milhões de indivíduos.

A quantidade de respondentes foi considerada satisfatória, tendo em vista a natureza de tal trabalho. Porém, caso a amostra fosse probabilística, poderia ser considerada uma margem de erro menor que 10\%. Assim, considerando a amostra de 179 respondentes, se tem 147 respondentes válidos, por se enquadrarem nas delimitações deste trabalho, o que resulta em uma margem de erro de $8,08 \%{ }^{4}$. Dos 147 respondentes válidos, 30,61\% são botafoguenses, $32,65 \%$ são flamenguistas, $29,93 \%$ são tricolores e $6,80 \%$ são vascaínos.

\subsection{Coleta de Dados}

Foi utilizado um questionário via plataforma Qualtrics ${ }^{5}$. O mesmo foi construido utilizando, em sua maior parte, a escala de Likert ${ }^{6}$, visando medir o nível de concordância dos respondentes em relação às perguntas realizadas. A distribuição do questionário foi feita principalmente via aplicativo móvel WhatsApp, com coleta entre os dias 16 de setembro e 7 de outubro de 2019.

Ademais, também foi utilizado o método Bola de Neve, solicitando para que os respondentes repassassem o questionário a outros indivíduos, visando maior alcance da pesquisa.

No questionário ${ }^{7}$ foram realizadas 14 perguntas, sendo 9 referentes à análise de percepção, opinião e impressões e 5 ao perfil do respondente, no qual todas seguiram o padrão de perguntas fechadas, ou seja, com respostas pré-definidas. As nove primeiras perguntas buscaram mapear as opiniões dos respondentes perante diferentes aspectos da transição de um clube para uma empresa, simulando diferentes cenários para tal e intenções (de interação com o clube, tais como torcida, associação, compra de produtos etc.) do mesmo

\footnotetext{
${ }^{4}$ Margem de erro calculada por meio do site Raosoft, utilizando a fórmula $E=\sqrt{\frac{(N-n) x}{n(N-1)}}$, sendo $n=\frac{N x}{\left((N-1) E^{2}+x\right)} \mathrm{e}$ $x=Z\left(\frac{c}{100}\right)^{2} r(100-r)$, no qual $n$ é o tamanho da amostra, $N$ é o tamanho da população, $r$ é a fração de respostas de interesse e $Z\left(\frac{c}{100}\right)$ é o valor crítico para o nível de confiança $c$.

${ }^{5}$ Qualtrics é um sistema online para realização de pesquisas, questionários, formulários etc.

${ }^{6}$ A escala de Likert é um sistema de escala psicométrica desenvolvido por Rensis Likert, que visa obter respostas em pesquisas de opinião, utilizando medição por nível de concordância.

7 Disponibilizado em https://bit.ly/futebolsa/. O mesmo se encontra no anexo deste trabalho.
} 
perante a situação. Já o segundo grupo de perguntas, contendo as cinco finais, buscou estabelecer o perfil do respondente, com perguntas para mapear seu perfil.

Destaca-se que as perguntas utilizadas têm como base, em relação à análise, tem como base o comportamento visto no dia a dia de forma geral dos indivíduos em relação a um comportamento relacionado ao esporte. Ademais, as mesmas foram mapeadas para cobrir cada um dos cenários previstos nos objetivos descritos, de forma individual e também fornecer uma visão geral do respondente sobre o tópico.

Para a coleta de dados, os dados obtidos na plataforma foram exportados para uma planilha da aplicação Microsoft Excel, ferramenta pela qual foram criados os gráficos e tabelas que ilustram o cenário obtido.

\subsection{Análise dos Dados}

Para a análise dos dados obtidos em tal processo, foi utilizada a abordagem quantitativa, que procura fornecer informações numéricas. O método foi utilizado visando obter um valor numérico para a percepção do consumidor perante o tópico analisado.

O tratamento dos dados foi feito utilizando estatística descritiva, com a média aritmética sendo o principal recurso utilizado, procurando obter o senso comum da amostra. A partir de tal, foram criados gráficos e tabelas, com uma visão global e com tabulação cruzada, visando exibir conexões entre os perfis observados.

Para a análise, foram utilizadas principalmente tabelas dinâmicas na ferramenta Microsoft Excel, sendo possível filtrar os resultados por diferentes perfis definidos pelas respostas obtidas na seção "Perfil do respondente" do questionário aplicado.

\subsection{Limitações do Método}

O método utilizado limita-se nos pontos de parcialidade, por não haver mecanismos para medir a tendência das respostas dos indivíduos ao vínculo com o seu time. Visando remediar a situação, o time do respondente só foi perguntado após as perguntas de análise.

Além disso, destaca-se que a média aritmética utilizada não considera variações, sendo assim, um fator limitante em certos pontos. 


\section{Análise de Resultados}

\subsection{Perfil dos Respondentes}

Conforme citado, o questionário foi dividido em duas partes, sendo que a primeira era composta pelas perguntas de análise e a segunda pelas perguntas de perfil.

Embora as questões de perfil tenham sido aplicadas ao final do questionário (pelos motivos citados previamente), as mesmas são analisadas antes, para apresentar o perfil dos respondentes antes de analisar as percepções dos mesmos.

O Gráfico 1 demonstra o time dos respondentes, que, conforme mencionado, possui o maior número de torcedores como adeptos do Clube de Regatas do Flamengo, com 32,65\%. Em seguida, se tem o Botafogo de Futebol e Regatas, com 30,61\%, seguido pelo Fluminense Football Club e pelo Clube de Regatas Vasco da Gama, com 29,93\% e 6,8\%, respectivamente.

Gráfico 1: Time dos respondentes

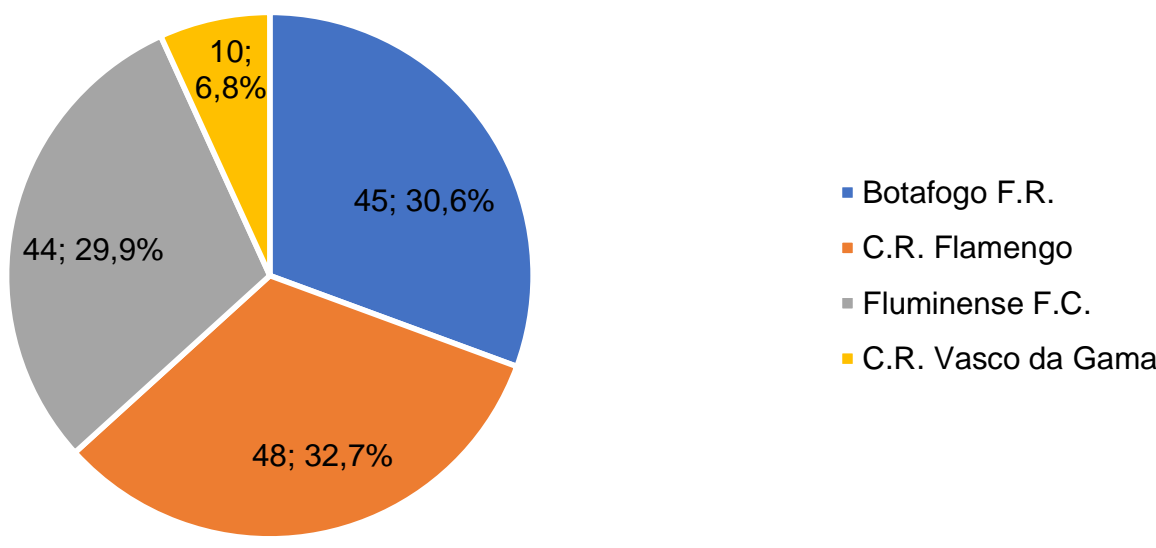

Fonte: Pesquisa de campo (2019). 
No Gráfico 2, percebe-se que a maior parte dos respondentes válidos, com $65,31 \%$, está entre 18 e 24 anos, enquanto a outra faixa, de 25 a 31, é representada por $34,69 \%$.

Gráfico 2: Idade dos respondentes

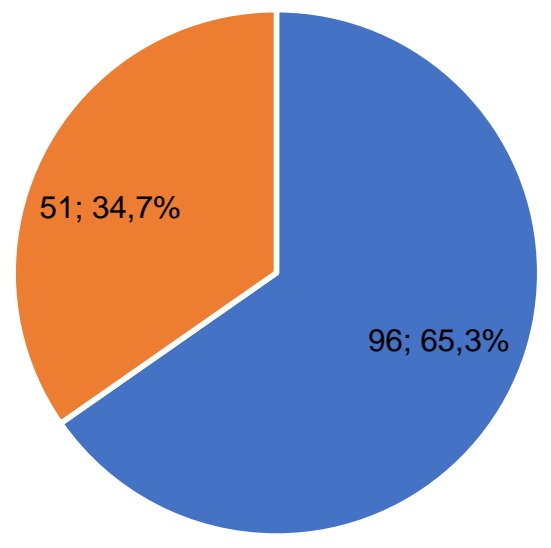

- Entre 18 e 24 anos

- Entre 25 e 31 anos

Fonte: Pesquisa de campo (2019).

O Gráfico 3 demonstra o gênero dos respondentes, no qual percebe-se uma divisão quase que igualitária, com $50,34 \%$ sendo do sexo masculino e $49,66 \%$ do feminino.

Gráfico 3: Gênero dos respondentes

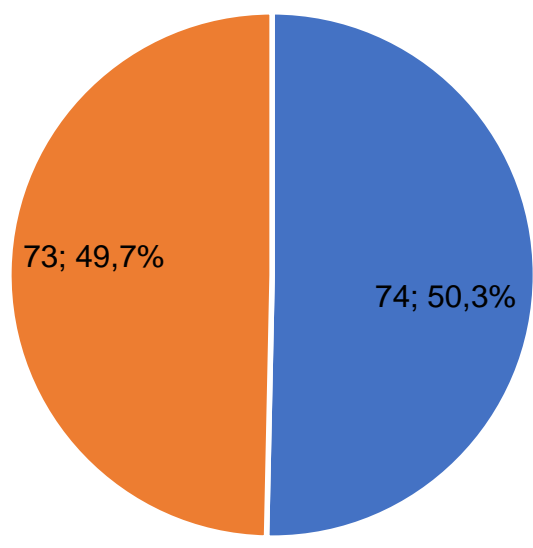

- Masculino

- Feminino

Fonte: Pesquisa de campo (2019). 
Em relação ao grau de escolaridade, conforme demonstrado no Gráfico 4, percebe-se uma concentração do público na faixa de ensino superior incompleto/cursando, com 70,07\% dos respondentes. A segunda faixa com maior participação corresponde ao ensino superior completo, com $23,13 \%$. As demais somam $6,8 \%$.

Gráfico 4: Grau de escolaridade dos respondentes

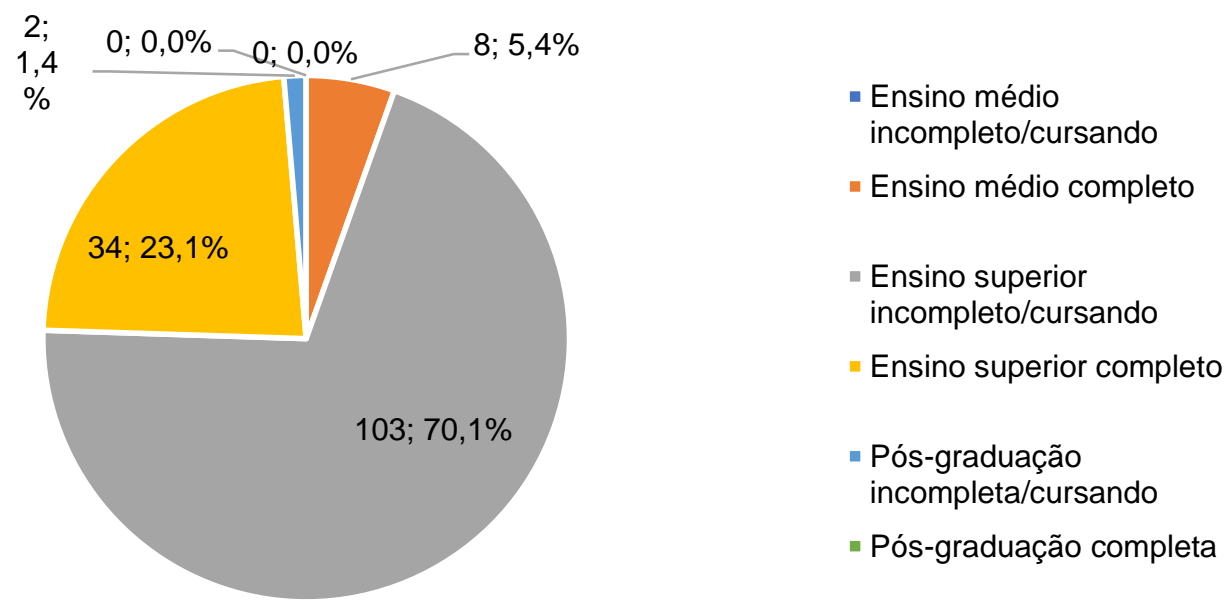

Fonte: Pesquisa de campo (2019).

Por fim, terminando as perguntas de perfil, se tem no Gráfico 5 a representação da renda familiar dos respondentes, que demonstra a classe $B$, que representa a faixa de renda mensal entre $R \$ 9.980,01$ e $R \$ 19.960,00$, com maior representatividade, com 53,06\%. $A$ classe $C$, de $R \$ 3.992,01$ a $R \$ 9.980,00$, segue com $21,77 \%$. Após, se tem a classe $A$, de renda maior que $R \$ 19.960,01$, com $17,01 \%$. As classes D e $E$, que, unificadas, são representadas pela renda mensal de até $\mathrm{R} \$ 3.992,00$, somam $8,16 \%$.

\footnotetext{
${ }^{8}$ Classes sociais definidas pelo Instituto de Brasileiro de Geografia e Estatística (IBGE), em matéria escrita pela British Broadcasting Corporation (BBC) no portal G1, do Globo, em 2019, contabilizando o salário mínimo de 2019, $\mathrm{R} \$ 998,00$ (salário mínimo obtido do site do Governo Federal, 2019).
} 
Gráfico 5: Renda familiar mensal dos respondentes

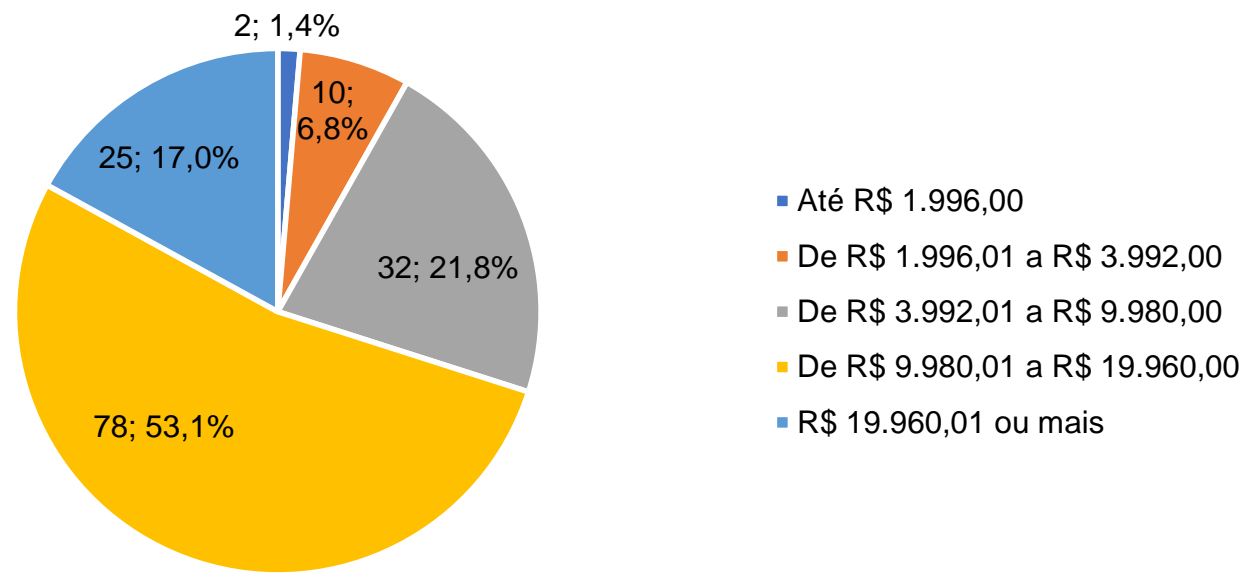

Fonte: Pesquisa de campo (2019).

\subsection{Comportamento dos Respondentes}

Primeiramente, analisando os dados obtidos, observa-se que, de forma geral, as informações de perfil apresentados, com exceção do time do respondente, não demonstram uma diferenciação notável em termos de opinião relacionada a idade, gênero, grau de escolaridade ou renda familiar.

Em relação ao comportamento dos respondentes, se tem, principalmente, a nona questão do questionário: "Marque as opções que se aplicam ao seu comportamento em relação ao seu clube". Tal pergunta visa medir o engajamento do respondente com seu clube e ao futebol, de forma geral. A mesma observa um nível de engajamento e intenção de participação do mesmo com seu clube.

Observando os 147 respondentes válidos no Gráfico 6, percebe-se que 84,35\% possuem uniforme do time, $72,11 \%$ acompanham notícias do clube, 62,59\% acompanham o clube nas redes sociais, $61,22 \%$ se esforçam para ver os jogos do time, $38,10 \%$ gostam de ir ao estádio, 22,45\% possuem produtos do clube que não sejam o uniforme, $6,12 \%$ são sócios da instituição e 1,36\% são membros de torcidas organizadas.

Ademais, pode-se afirmar que $94,56 \%$ dos respondentes possuem alguma relação (das listadas acima) com seu clube, enquanto 5,44\% não se encaixam em nenhuma posição. 
Gráfico 6: Comportamento do respondente em relação ao clube

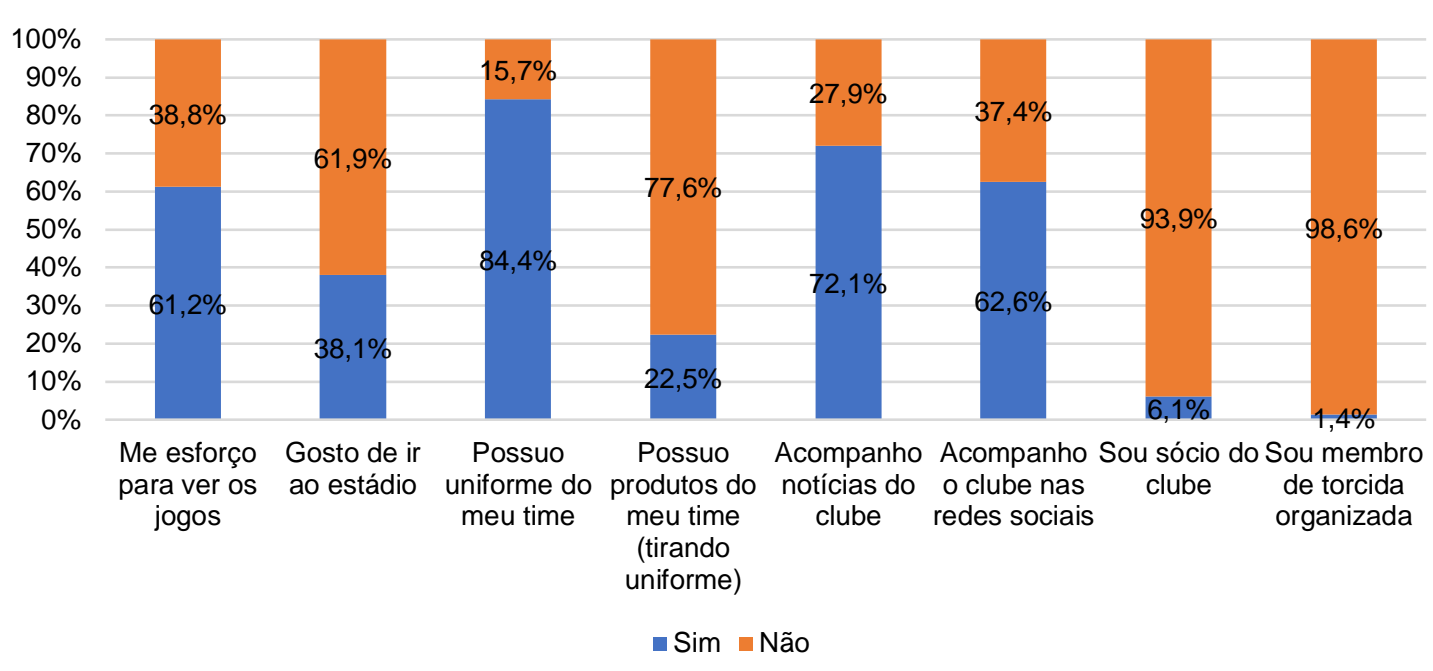

Fonte: Pesquisa de campo (2019).

\subsection{Empresas no Futebol}

Observando o Gráfico 7, percebe-se que $72,8 \%$ dos respondentes concordam, em algum nível, com a ideia de investidores comprarem clubes. Isso pode ser vinculado a alguns fatores já exemplificados ao longo deste trabalho, como a tendência de se falar em clubesempresas hoje, de sociedades anônimas do futebol (SAF), sociedades de propósito específico (SPE) no futebol etc. Ademais, também pode-se levar em conta o atual cenário financeiro da maior parte dos clubes da cidade, que, com exceção do Flamengo, vivem graves crises financeiras.

Destaca-se que tal transformação pode levar o clube a um caminho não previsto pelos seus torcedores. Uma transformação do clube em S.A. faz com que o mesmo vise o lucro sob comando de um (ou mais) dono(s). Portanto, caso a instituição não esteja correspondendo, o mesmo pode tomar medidas mais drásticas para tentar atingir seu objetivo.

Porém, também se tem o modelo de cessão de direitos (conforme aplicado no Projeto Botafogo S/A), que prevê um "empréstimo" remunerado dos direitos de marca, imagem e ativos do clube social a uma SPE, que, por vez, não possuí direitos definitivos sobre os atributos citados. Tal modelo é mais conservador e cauteloso do ponto de vista da instituição.

Assim, existem diversos cenários possíveis para um futuro com tal modificação. Destaca-se que o torcedor pode, ou não, estar ciente de tal, o que, consequentemente, pode afetar sua percepção em relação ao tema. 
Gráfico 7: Opinião em relação à ideia de investidores comprarem clubes

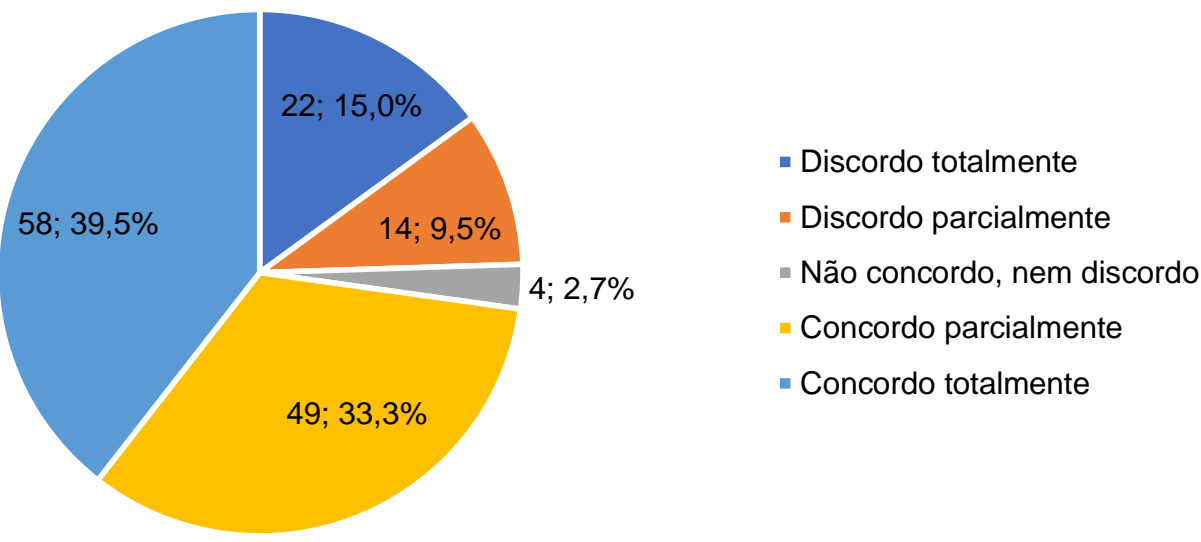

Fonte: Pesquisa de campo (2019).

O Gráfico 8 demonstra que, dos 72,79\% que concordam, em algum nível, com a ideia, os flamenguistas são os que menos são agradados pela mesma, com $68,75 \%$ de desaprovação, possível reflexo do panorama citado. Já em relação aos outros três clubes, todos possuem índices de aprovação superiores a 90\%.

Gráfico 8: Opinião dos torcedores em relação à ideia de compra dos clubes

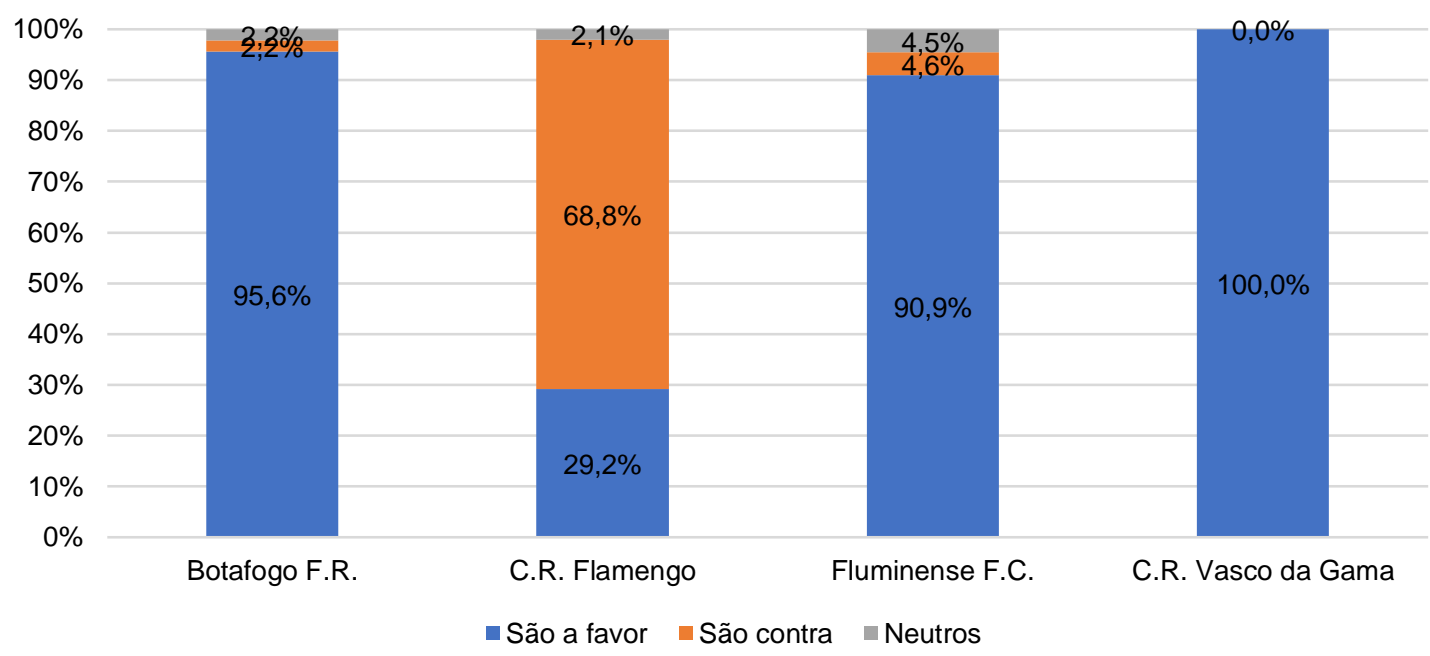

Fonte: Pesquisa de campo (2019).

Em relação à segunda pergunta, cujo objetivo era medir quantos dos respondentes gostariam de investir em um clube de futebol, o que, pela natureza estatutária dos quatro 
clubes, seria possível somente caso os mesmos fossem empresas, teve maior parte dos respondentes, com 52,38\%, concordando em algum nível com a afirmação apresentada, conforme demonstrado no Gráfico 9.

Gráfico 9: Opinião dos respondentes em relação à ideia de investir em um clube

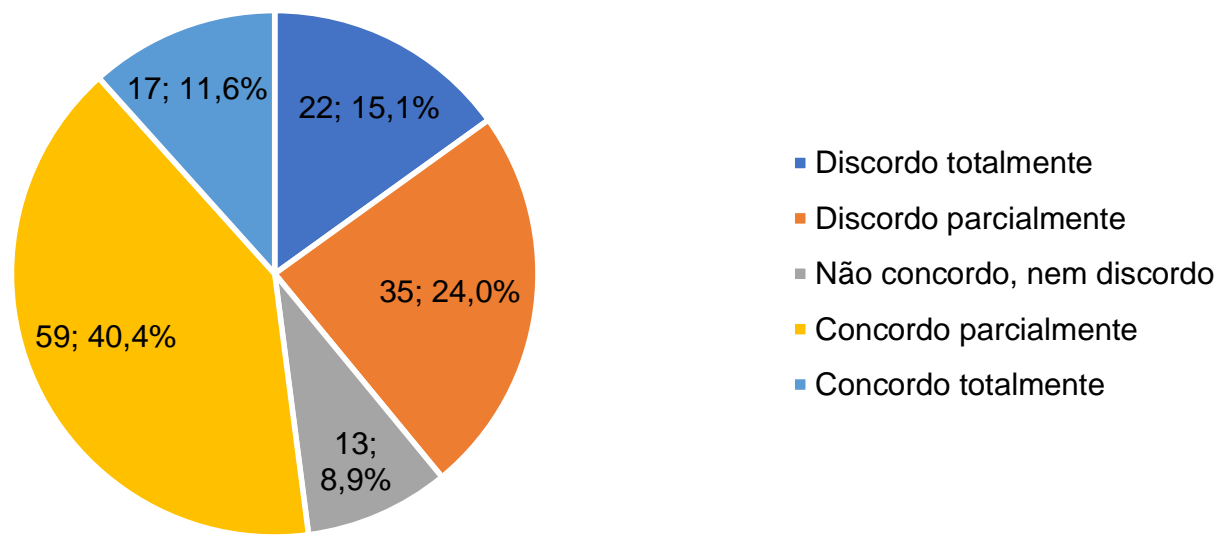

Fonte: Pesquisa de campo (2019).

Os resultados reforçam o cenário apresentado anteriormente, pois apenas $29,17 \%$ dos flamenguistas afirmaram gostar da ideia, enquanto Botafogo, Fluminense e Vasco tiveram números de $75,56 \%, 56,82 \%$ e $40 \%$, respectivamente. O resultado também demonstra que os vascaínos gostam da ideia de investidores no clube, porém, os mesmos não querem contribuir com o projeto. Por outro lado, o elevado índice vinculado ao Botafogo pode estar relacionado ao progresso recente do clube em relação a tal mudança, visando se transformar em empresa. Com um projeto realizado pela consultoria Ernst \& Young, o alvinegro, conforme já dito, tem conversas avançadas com investidores, brasileiros e estrangeiros, para alavancar o potencial financeiro do clube, já para a temporada 2020. Com grandes nomes do mercado no projeto (como os irmãos Moreira Salles), o mesmo transmite credibilidade, o que pode ser um fator para explicar os resultados obtidos.

O Gráfico 10 demonstra a relação dos respondentes em relação à possibilidade de ajudar o clube financeiramente, caso o mesmo precise. Nessa hipótese, a maior parte dos respondentes, com 56,46\%, rejeitam, em algum nível, a ideia. $34,01 \%$ concordam, em algum nível, que ajudariam seus respectivos clubes. 
Gráfico 10: Opinião dos respondentes em relação à possibilidade de ajudar seu clube financeiramente

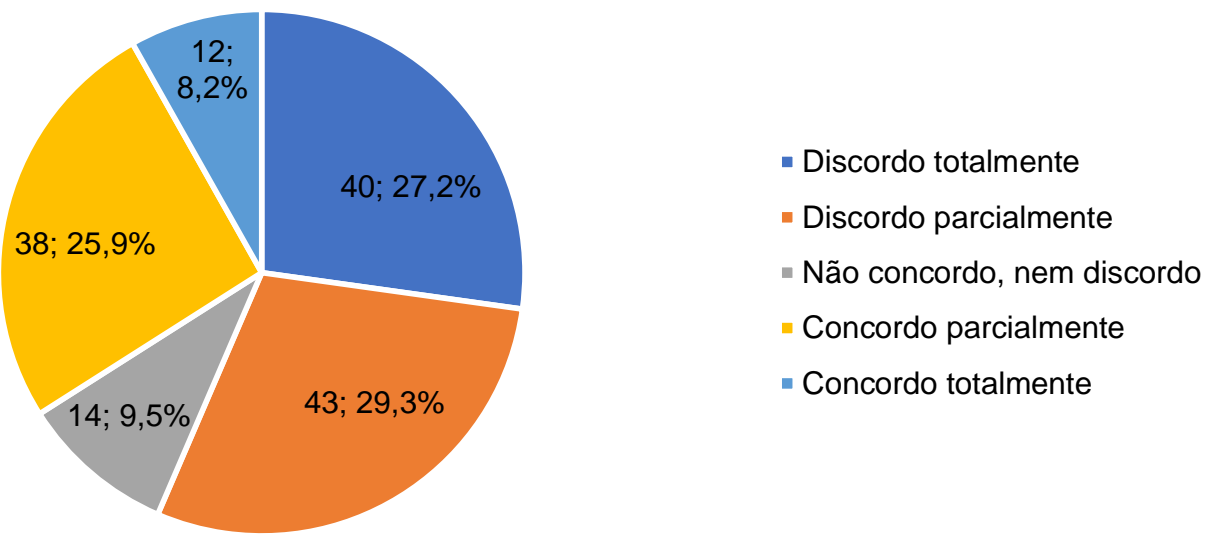

Fonte: Pesquisa de campo (2019).

Tais respostas podem ser reflexo de gestões não confiáveis nos clubes de futebol, com participações em contratos obscuros, envolvimentos em ilegalidades, corrupção etc. Existem questões, como confiança, real retorno esportivo e nível de envolvimento, que são fundamentais para tal ação e, o torcedor pode ter preocupações em relação aos mesmos.

Mantendo o cenário visto anteriormente, os vascaínos tendem a não gostar da ideia de não somente investir, mas também ajudar o clube financeiramente. $20 \%$ dos cruzmaltinos afirmam que estariam dispostos. Para os outros três clubes, o índice de aprovação se manteve relativamente próximo, com 33,33\%, 35,42\% e 36,36\%, para Botafogo, Flamengo e Fluminense, respectivamente.

Em relação a percepção do torcedor para a mudança de clube ou associação para empresa, percebe-se, conforme demonstrado no Gráfico 11, que 83,67\% acreditam que tal transformação possa, em algum nível, fazer com que o mesmo passe a ter um potencial maior de investimento, brigar por títulos etc., embora também existam riscos, conforme citados, talvez não percebidos pelos respondentes. 
Gráfico 11: Percepção do torcedor em relação aos resultados de uma possível mudança

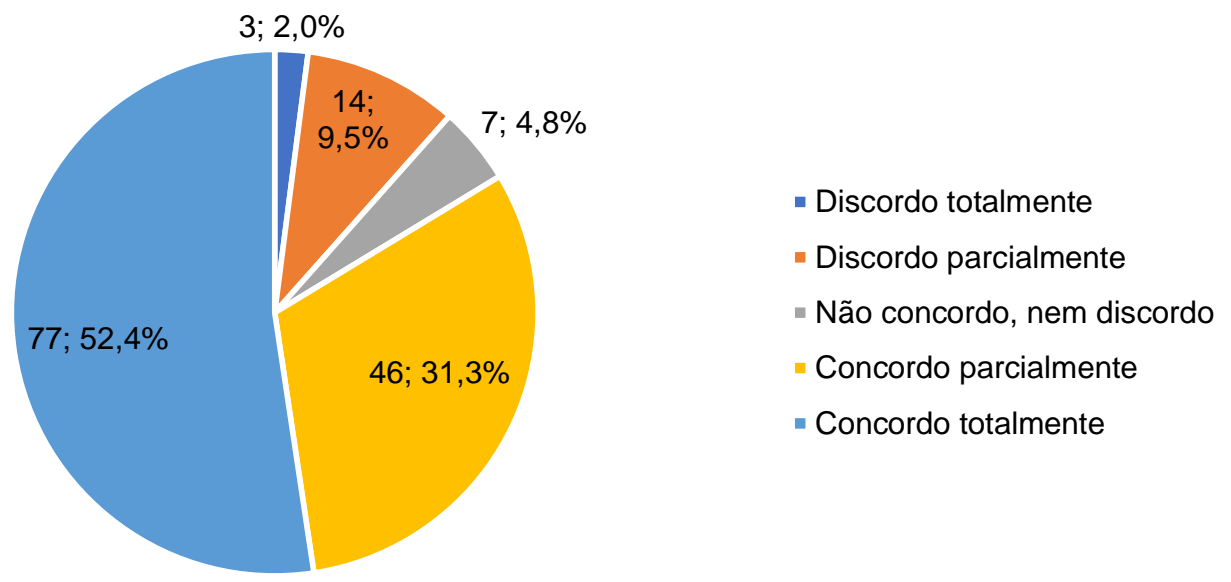

Fonte: Pesquisa de campo (2019).

Também compatível com os cenários apresentados, o índice de concordância é nitidamente inferior entre os flamenguistas, dos quais $42,67 \%$ não acreditam em tal afirmativa. Por outro lado, botafoguenses, tricolores e cruzmaltinos acreditam, com percentuais de $95,56 \%, 95,45 \%$ e $100 \%$, respectivamente.

Seguindo em uma parte mais direta do questionário, analisa-se a opinião dos respondentes perante a ideia de um clube se tornar uma empresa, de forma clara e transparente. Como visto no Gráfico 12, 63,39\% são a favor, em algum nível, da mudança, o que retrata não somente a tendência a gostar de investimento nos clubes, mas também uma mudança institucional. A mesma pode ser explicada pelos constantes pedidos das torcidas de Botafogo, Fluminense e Vasco, por clubes mais organizados e profissionais, algo que, atualmente, não é visto, devido à estrutura estatutária dos clubes, que exige presidências amadoras nos mesmos. No caso do Flamengo, percebe-se uma diferença no estatuto, que, além do presidente amador, inclui um CEO profissional para comando do clube a seu lado, além de vice-presidentes remunerados. 
Gráfico 12: Opinião dos torcedores em relação à mudança institucional dos clubes

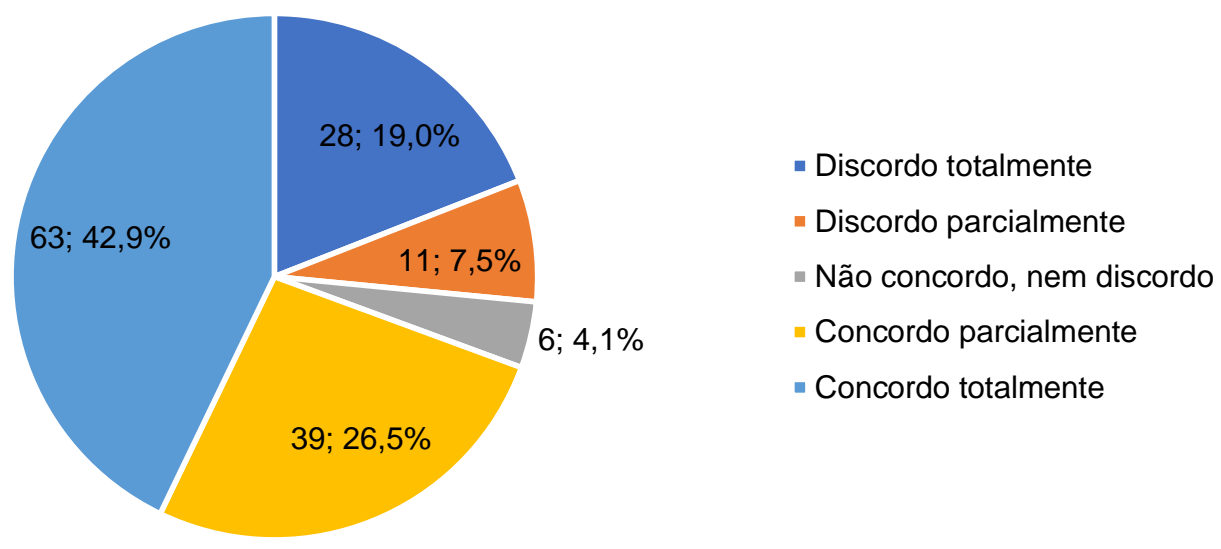

Fonte: Pesquisa de campo (2019).

O cenário também reforça os resultados obtidos, com apenas $22,92 \%$ dos rubronegros sendo favoráveis à ideia $\mathrm{e}$, consequentemente, preferindo o modelo de clube/associação.

A pergunta seguinte seguiu um modelo condicional, sendo exibida apenas para os respondentes que não rejeitaram completamente a hipótese anterior, ou seja, apenas para respondentes que não discordaram totalmente. Tendo isso em mente, nota-se que para a mesma, foram obtidos 119 respondentes válidos.

Em tal questão, conforme demonstrado no Gráfico 13, 89,92\% dos respondentes rejeitaram a afirmativa, que, por vez demonstrava um cenário de transição de clube para empresa, porém, com alterações na identidade do clube (escudo, bandeira, uniforme, cores, hino etc.). Tal cenário é relativamente fácil de prever e ser explicado, pelo fato de que os quatro clubes são instituições centenárias ${ }^{9}$, com anos de tradição, que é amplamente apreciada por seus adeptos.

\footnotetext{
9 Botafogo foi fundado em 1894 (como Clube de Regatas Botafogo); Flamengo em 1895; Fluminense em 1902; e Vasco em 1898. Vale destacar que, com exceção do Fluminense, os clubes foram fundados sem prática de futebol, atuando inicialmente apenas no remo.
} 
Gráfico 13: Opinião dos torcedores em relação à transformação com alteração da identidade dos clubes

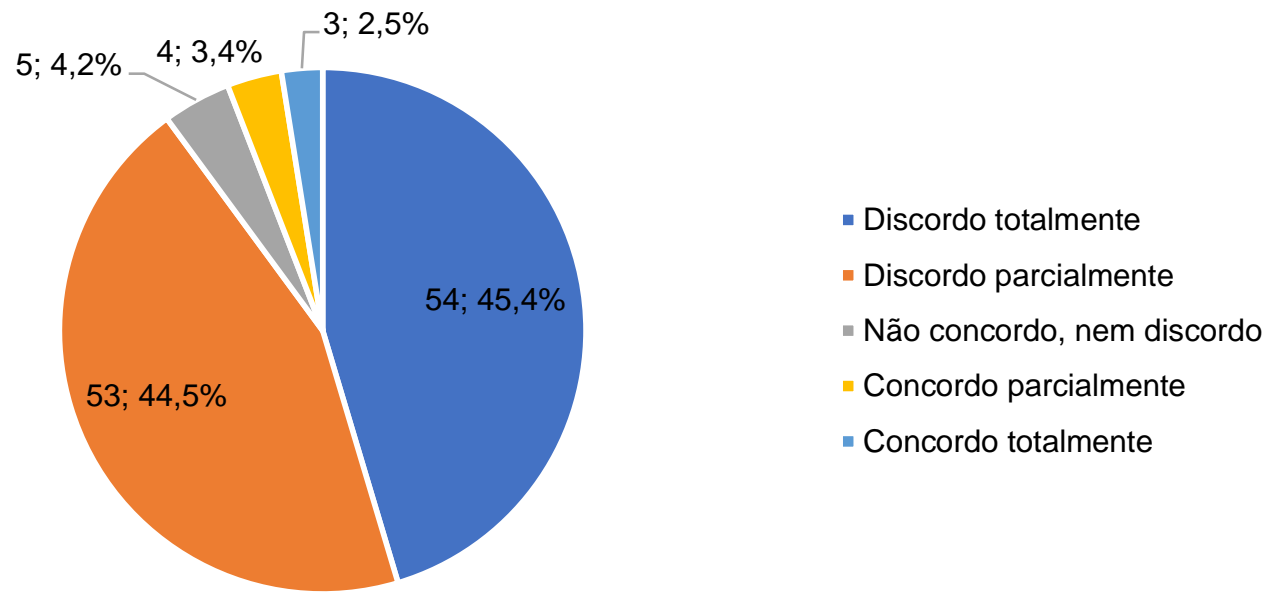

Fonte: Pesquisa de campo (2019).

Porém, mesmo com elevada rejeição ao tópico, os torcedores, com $85,72 \%$ dos respondentes, afirmam que mesmo no caso de acontecimento do cenário descrito, os mesmos não deixariam de torcer para seus clubes, conforme exibido no Gráfico 14.

Gráfico 14: Percepção do torcedor em relação a relevância da identidade do clube

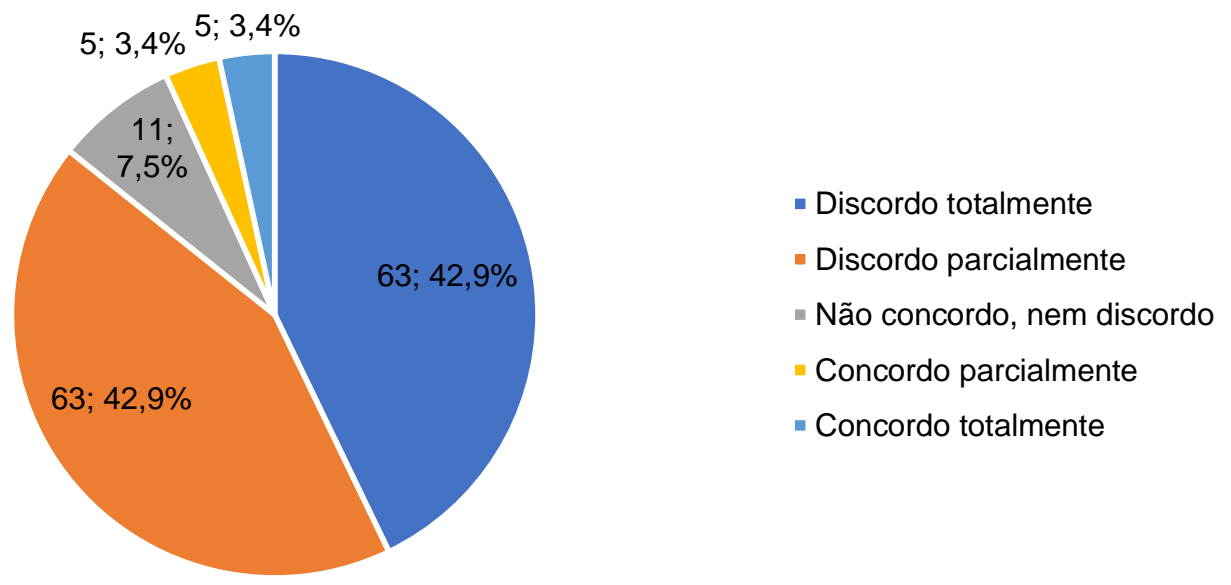

Fonte: Pesquisa de campo (2019).

Em seguida, foi pedido aos respondentes para listar, em ordem de preferência, alguns possíveis resultados da transição citada. A Tabela 1 demonstra os resultados obtidos, que listam como preferência, um maior potencial de investimento, com 88,44\% de preferência 
imediata, seguido pela abertura de capital, com 8,84\%. Em tal tabela, é possível observar como os respondentes ordenaram os tópicos.

Tabela 1: Opinião dos respondentes em relação a aspectos de uma possível mudança

\begin{tabular}{|c|c|c|c|c|c|}
\hline Preferência & $1^{a}$ & $2^{a}$ & $3^{\mathrm{a}}$ & $4^{\mathrm{a}}$ & $5^{\mathrm{a}}$ \\
\hline $\begin{array}{l}\text { Maior poder de } \\
\text { investimento }\end{array}$ & $\begin{array}{c}130 \\
88,44 \%\end{array}$ & $\begin{array}{c}12 \\
12 \%\end{array}$ & $\begin{array}{c}1 \\
0,68 \%\end{array}$ & $\begin{array}{c}1 \\
0,68 \%\end{array}$ & $\begin{array}{c}3 \\
2,04 \%\end{array}$ \\
\hline Abertura de capital & $\begin{array}{c}13 \\
8,84 \%\end{array}$ & $\begin{array}{c}119 \\
80,95 \%\end{array}$ & $\begin{array}{c}11 \\
7,48 \%\end{array}$ & $\begin{array}{c}2 \\
1,36 \%\end{array}$ & $\begin{array}{c}2 \\
1,36 \%\end{array}$ \\
\hline Clube com dono(s) & $\begin{array}{c}1 \\
0,68 \%\end{array}$ & $\begin{array}{c}6 \\
4,08 \%\end{array}$ & $\begin{array}{c}109 \\
74,15 \%\end{array}$ & $\begin{array}{c}20 \\
13,61 \%\end{array}$ & $\begin{array}{c}11 \\
7,48 \%\end{array}$ \\
\hline $\begin{array}{c}\text { Maior Ilberdade do } \\
\text { estatuto }\end{array}$ & $\begin{array}{c}0 \\
0 \%\end{array}$ & $\begin{array}{c}8 \\
5,44 \%\end{array}$ & $\begin{array}{c}25 \\
17,01 \%\end{array}$ & $\begin{array}{c}113 \\
76,87 \%\end{array}$ & $\begin{array}{c}1 \\
0,68 \%\end{array}$ \\
\hline $\begin{array}{l}\text { Possibilidade de } \\
\text { mudança de tradicões }\end{array}$ & $\begin{array}{c}3 \\
2,04 \%\end{array}$ & $\begin{array}{c}2 \\
1,36 \%\end{array}$ & $\begin{array}{c}1 \\
0,68 \%\end{array}$ & $\begin{array}{c}11 \\
7,48 \%\end{array}$ & $\begin{array}{c}130 \\
88,44 \%\end{array}$ \\
\hline
\end{tabular}

Fonte: Pesquisa de campo (2019). 


\section{Conclusão}

O principal objetivo deste trabalho foi identificar as opiniões dos torcedores cariocas em relação à tendência vista no cenário do futebol brasileiro, clubes-empresas, ou, mais especificamente, sociedades anônimas do futebol e derivadas (SPEs e SAFs).

Analisando as respostas obtidas no questionário, percebe-se claramente uma resistência por parte da torcida do Flamengo em relação a tal mudança, à transformação do clube em empresa. Por outro lado, os torcedores dos outros três clubes veem a mesma como positiva. Tal diferenciação, conforme citado, pode ser explicada pelo momento financeiro vivido pelos clubes, no qual o rubro negro está em alta no mercado, com patrocinadores e caixa, fazendo contratações de peso, enquanto os outros três vivem graves crises financeiras ${ }^{10} \mathrm{e}$, consequentemente, um desempenho não tão bom dentro de campo.

A opinião observada pode ser atrelada a um receio de mudança, pelo qual o torcedor carioca acredita que uma mudança estrutural grande como a analisada pode não dar certo (como no caso do Flamengo) e terminar com a boa fase do clube, enquanto os outros estão dispostos a arriscar mais e desejar mudanças, já que o modelo atual não vem dando tantos resultados positivos. O resultado acompanha todas configurações demográficas analisadas, se mostrando realmente uma questão de fase do clube, e não uma questão sociocultural.

Destaca-se que uma mudança de tal porte em uma instituição dentre as citadas, centenárias e de enorme peso, possui grandes impactos no ambiente, passando por aspectos econômicos (investimentos, contratos de patrocínio, cessão de direitos etc.), socioculturais (comportamento dos torcedores, cultura esportiva etc.), político-legais (lei de incentivo ao esporte, lei das SAFs etc.), dentre outros.

Em relação às implicações gerenciais, os clubes, por meio do presente trabalho, podem perceber que a opinião do torcedor, de forma geral, se dá não por uma análise específica sobre o tema, mas por uma questão do potencial atual do mesmo, disputa por títulos e competitividade, esportiva e financeiramente. É uma tendência que os torcedores

10 Segundo o Itaú BBA (em matéria publicada pelo jornal Gazeta do Povo em 2019), o Botafogo é clube mais endividado do país, com 672 milhões de reais em dívidas. O Vasco da Gama é o detentor da terceira maior dívida, com 496 milhões de débitos. Já o tricolor carioca, se encontra em sétimo, com 420 milhões. O Flamengo possui 418 milhões de dívidas e ocupa a nona colocação, porém, suas dívidas se concentram a mais longo prazo. 
aceitem (e apoiem) tal transformação com mais facilidade no caso do clube estar passando por dificuldades no modelo de associação, enquanto, sem dificuldades, exista uma certa rejeição. Portanto, destaca-se o valor da marca de um clube, juntamente a sua identidade e atributos, como os principais ativos dele na percepção de seus adeptos.

Também se destaca que, em qualquer situação dos clubes, os torcedores não são favoráveis à mudança estrutura, caso o clube perca a sua identidade, algo que é amplamente valorizado no Rio de Janeiro. Por outro lado, os mesmos afirmam não deixar de torcer para o clube em caso de mudanças, mesmo que não as aprovem. Sendo assim, é percebido que, para maior apoio e aceitação, os clubes que planejem se tornar empresas façam contratos bem estruturados para manutenção da marca e história, como também visto no Botafogo, que prevê uma cessão da marca Botafogo, pelo período de trinta anos, a uma sociedade de propósito específico criada para gestão do futebol do alvinegro por um grupo de investidores (GLOBO ESPORTE, 2019). Nesse caso, a SPE poderá gerir a marca Botafogo e será detentora dos direitos desta, porém, não poderá fazer alterações em relação ao nome, símbolo e derivados.

Concluindo, destaca-se que, no âmbito acadêmico, um campo a ser estudado, em uma pesquisa futura relacionada ao tema é a questão estrutural e organizacional das sociedades anônimas no futebol, o que pode ser acompanhado de perto com o processo que vem sendo estruturado no Botafogo, chamado internamente de "Botafogo S/A"11. Mesmo que o modelo não seja inédito (com alguns clubes ao redor do mundo já ativos com o modelo, como Juventus F.C., Chelsea F.C. e Paris Saint-Germain F.C., por exemplo, da Itália, Inglaterra e França, respectivamente), o mesmo é inédito para um clube de grande porte nacional. Ademais, mesmo que o modelo exista de forma similar em outras localidades, a legislação e estrutura adotada possuem certas variações, portanto, uma análise em tais moldes em terras brasileiras seria de fato uma exploração ainda não realizada com situações reais sendo postas em prática.

Ademais, percebe-se que todos os objetivos citados no início deste trabalho foram atingidos e devidamente analisados.

\footnotetext{
${ }^{11}$ O nome oficial da empresa ainda não foi divulgado. A empresa, se aprovado o projeto, em reunião extraordinária do Conselho Deliberativo da instituição, será a responsável pelo controle do fundo de investimento formado pelos investidores (estimado no valor de 400 milhões de reais) terá a concessão da marca Botafogo de Futebol e Regatas e seus ativos relacionados ao futebol para os próximos trinta anos, a partir de janeiro de 2020 (GOIS, 2019).
} 


\section{Referências Bibliográficas}

AAKER, D. Building strong brands. New York: The Free Press, 1996.

AAKER, D. Managing brand equity. New York: The Free Press, 1991.

AMERICAN MARKETING ASSOCIATION. Dictionary. Disponível em: $<$ https://www.ama.org/resources/Pages/Dictionary.aspx?dLetter=B> Acesso em: 01 de junho de 2019.

AMERICAN MARKETING ASSOCIATION. The definition of marketing. Disponível em: <https://www.ama.org/the-definition-of-marketing/> Acesso em: 20 de agosto de 2019.

BBC. Por que a classe média está ficando muito endividada em vários lugares do mundo, segundo a OCDE. Disponível em: $<$ https://g1.globo.com/economia/noticia/2019/04/10/por-que-a-classe-media-ficando-muitoendividada-em-varios-lugares-do-mundo-segundo-a-ocde.ghtml> Acesso em: 21 de ago. 2019.

BERTOLDO, Camila. Marketing esportivo: O Esporte nas Categorias Empresariais: São Paulo: UMESP, 2000.

BRANDÃO, Vladmir. A percepção do consumidor: uma estratégia de marketing. Rio de Janeiro: UFRRJ, 2009.

BRASIL. Lei № 6.404, de 15 de dezembro de 1976. Disponível em: <http://www.planalto.gov.br/ccivil_03/leis//6404consol.htm> Acesso em: 01 de junho de 2019. CAPELO, Rodrigo. Entenda o plano encomendado pelos Moreira Salles para salvar o futebol do Botafogo com a S/A. Disponível em: <https://globoesporte.globo.com/blogs/blogdo-rodrigo-capelo/post/2019/07/26/entenda-o-plano-encomendado-pelos-moreira-sallespara-salvar-o-futebol-do-botafogo-com-a-sa.ghtml> Acesso em: 21 ago. 2019.

CAPELO, Rodrigo. Revenda de jogadores, sociedade anônima e transparência: as lições do Porto para o futebol brasileiro. Disponível em: <https://globoesporte.globo.com/blogs/blog-do-rodrigo-capelo/post/2019/04/10/revenda-dejogadores-sociedade-anonima-e-transparencia-as-licoes-do-porto-para-o-futebolbrasileiro.ghtml> Acesso em: 21 ago. 2019. 
CERIONI, Clara. Flamengo é o time que mais fatura no Brasil. Disponível em: <https://exame.abril.com.br/negocios/flamengo-e-o-time-que-mais-arrecada-dinheiro-nobrasil-revela-pesquisa/> Acesso em: 27 abr. 2019.

CHADE, Jamil. Receita do futebol supera $\mathbf{R} \$ 100$ bi e esporte já é maior que PIB de 95 países. Disponível em: <https://esportes.estadao.com.br/noticias/futebol,receita-do-futebolsupera-r-100-bi-e-esporte-ja-e-maior-que-pib-de-95-paises,70002340625> Acesso em: 27 abr. 2019.

CHURCHILL, G.; PETER, J. Marketing: Criando Valor para os Clientes: 3 ed. São Paulo: Saraiva, 2013.

CONFEDERAÇÃO BRASILEIRA DE FUTEBOL. Ranking da CBF 2019: Palmeiras lidera lista; Cruzeiro é segundo. Disponível em: <https://www.cbf.com.br/futebolbrasileiro/noticias/campeonato-brasileiro/palmeiras-assume-ponta-isolada-do-rankingnacional-de-clubes-da-cbf> Acesso em: 21 ago. 2019.

CONTURSI, E. Marketing esportivo. 2 ed. Rio de Janeiro: Sprint, 1996.

CORRÊA-LIMA, O. Sociedade anônima: 3 ed. Belo Horizonte: Del Rey, 2005.

ÉPOCA NEGÓCIOS. Red Bull Brasil investe R\$ 45 milhões e assume o comando do Bragantino. Disponível em: <https://epocanegocios.globo.com/Mercado/noticia/2019/03/epoca-negocios-red-bull-brasilinveste-r-45-milhoes-e-assume-o-comando-do-bragantino.html> Acesso em: 11 jul. 2019.

ENGEL, J. F.; BLACKWELL, R. D.; MINIARD, P. W. Comportamento do consumidor. 8 ed. Rio de Janeiro: Livros Técnicos e Científicos, 2000.

GAZETA DO POVO. Ranking das dívidas 2019: estudo revela situação financeira dos clubes brasileiros. Disponível em: <https://www.gazetadopovo.com.br/esportes/dividasclubes-futebol-brasileiro/> Acesso em: 22 out. 2019.

GLOBO ESPORTE. Análise Itaú BBA mostra faturamento recorde de brasileiros, mas prevê problemas. Disponível em: <https://globoesporte.globo.com/futebol/brasileirao-seriea/noticia/analise-itau-bba-mostra-faturamento-recorde-de-brasileiros-mas-preveproblemas.ghtml> Acesso em: 27 abr. 2019.

GLOBO ESPORTE. Pesquisa mostra torcida do Fla com grande vantagem sobre rivais no Rio. Disponível em: <http://globoesporte.globo.com/futebol/noticia/2014/08/pesquisamostra-torcida-do-fla-com-grande-vantagem-sobre-rivais-no-rio.html> Acesso em: 07 out. 2019. 
GOIS, Ancelmo. Botafogo: fundo de investidores para o futebol terá cota mínima de $\mathbf{R} \$$ 10 milhões. Disponível em: <https://blogs.oglobo.globo.com/ancelmo/post/botafogo-fundode-investidores-para-o-futebol-tera-cota-minima-de-r-10-milhoes.html> Acesso em: 01 nov. 2019.

GOVERNO FEDERAL. Decreto no 9.661, de 1을 de janeiro de 2019. Disponível em: < http://www.planalto.gov.br/ccivil_03/_Ato2019-2022/2019/Decreto/D9661.htm> Acesso em: 20 jul. 2019.

HUGHES, Matt. Roman Abramovich sets £2.5bn price tag on Chelsea. Disponível em: $<$ https://www.thetimes.co.uk/article/roman-abramovich-sets-2-5bn-price-tag-on-chelseahbfj30cj> Acesso em: 23 ago. 2019.

IBGE. IBGE divulga as estimativas da população dos municípios para 2019. Disponível em: $\quad$ <https://agenciadenoticias.ibge.gov.br/agencia-sala-de-imprensa/2013-agencia-denoticias/releases/25278-ibge-divulga-as-estimativas-da-populacao-dos-municipios-para2019> Acesso em: 18 set. 2019.

JAMIESON, Susan. Likert scale. Disponível em: <https://www.britannica.com/topic/LikertScale> Acesso em: 23 set. 2019.

KARSAKLIAN, E. Comportamento do consumidor: 2 ed. São Paulo: Atlas, 2004.

KELLER, K. Conceptualizing, measuring, and managing customer-based brand equity: Chicago: Journal of Marketing, 1993.

KELLER, K.; MACHADO, M. Gestão estratégica de marcas: São Paulo: Pearson, 2006.

KOHLI, C.; LEUTHESSER, L. Brand equity: capitalizing on intellectual capital: London: Ivey Business Journal, 2001.

KOTLER, P.; ARMSTRONG, G. Princípios de marketing: 12 ed. São Paulo: Pearson, 2008. KOTLER, P.; KELLER, K. Administração de marketing: 14 ed. São Paulo: Pearson, 2012. LANCE! Estudo mostra os clubes mais endividados do futebol brasileiro. Disponível em: $<$ https://www.lance.com.br/futebol-nacional/saiu-ranking-dos-clubes-mais-endividadosfutebol-brasileiro.html> Acesso em: 11 jul. 2019.

MULLIN, B.; HARDY, S.; SUTTON, W. Marketing esportivo: 2 ed. Porto Alegre: Artmed/Bookman, 2004.

PEDERSEN, P.; PARKS, J.; QUARTERMAN, J.; THIBAULT, L. Contemporary sport management: 4 ed. Windsor: Human Kinetics, 2011. 
PITTS, B.; STOTLAR, D. Fundamentos de marketing esportivo. São Paulo: Phorte Editora, 2002.

RAOSOFT. Sample size calculator. Disponível em: <http://www.raosoft.com/samplesize.html> Acesso em: 08 out. 2019.

REIN, I.; KOTLER, P.; SHIELDS, B. The elusive fan: Reinventing Sports in a Crowded Marketplace: New York: McGraw-Hill, 2006.

RUDNICK, F. Investidor estrangeiro? Time de dono? Novo patamar? Tudo sobre Athletico S/A. Disponível em: <https://www.gazetadopovo.com.br/esportes/atleticopr/investidor-estrangeiro-time-de-dono-novo-patamar-tudo-sobre-athletico-sac2ejspyl2en4gifb890pcgrlr/> Acesso em: 11 jul. 2019.

SANTANA, Sergio. Consultoria aprova, e Irmãos Moreira Salles terão reunião com o Botafogo. Disponível em: <https://www.lance.com.br/botafogo/consultoria-aprova-irmaosmoreira-salles-terao-reuniao-com-botafogo.html> Acesso em: 12 ago. 2019.

SCHIFFMAN, L. G.; KANUK, L. L. Comportamento do consumidor. Rio de Janeiro: Livros Técnicos e Científicos, 2000.

SIGNIFICADOS. Significado de sociedade anônima. Disponível em: <https://www.significados.com.br/sociedade-anonima/> Acesso em: 01 jun. 2019.

SÓ CONTABILIDADE. Lei das S.A. Disponível em: <https://www.socontabilidade.com.br/leisSA.php> Acesso em: 01 jun. 2019.

SOBRAL, F.; PECI, A. Administração: Teoria e prática no contexto brasileiro: 2 ed. São Paulo: Pearson, 2013.

SOLOMON, M. Consumer behavior: 10 ed. Essex: Pearson, 2013.

SOLOMON, M. O comportamento do consumidor: Comprando, possuindo e sendo: 11 ed. Porto Alegre: Bookman, 2016.

THE CHARTERED INSTITUTE OF MARKETING. Get into marketing. Disponível em: <https://www.cim.co.uk/qualifications/get-into-marketing/> Acesso em: 20 de agosto de 2019.

SUNERSON, G. Super Bowl LIII: What a Super Bowl commercial cost the year you were born. Disponível em: <https://www.usatoday.com/story/money/2019/02/01/what-a-superbowl-commercial-cost-the-year-you-were-born/38980061/> Acesso em: 20 de agosto de 2019. 
SCHWARTZ, N. How much does a 2019 Super Bowl commercial cost? Disponível em: <https://ftw.usatoday.com/2019/02/2019-super-bowl-commercial-cost> Acesso em: 20 de agosto de 2019.

SEEDORF, Clarence. Clarence Seedorf will be playing for Botafogo. Disponível em: $<$ http://seedorf.com/EN/news/clarence_seedorf_will_be_playing_for_botafogo.aspx> Acesso em: 30 nov. 2019.

VERGARA, S. Métodos de pesquisa em administração: 9 ed. São Paulo: Atlas, 2007.

WHEELER, A. Designing brand identity: 5 ed. New Jersey: Wiley, 2018. 


\section{Anexo}

\section{Sociedades anônimas no futebol.}

Agradeço sua participação em tal questionário.

Tenha em mente que não existem respostas certas ou erradas, apenas opiniões.

Esta pesquisa é 100\% anônima.

Vale destacar que após responder uma pergunta, não é possível alterar sua resposta.

Por Gabriel S. Cardia

A seguir, marque a opção que melhor descreve a sua opinião em relação as afirmativas descritas em relação aos 4 grandes clubes de futebol da cidade do Rio de Janeiro.

Gosto da ideia de investidores comprarem clubes.

Discordo totalmente

Discordo parcialmente

Não concordo, nem discordo

Concordo
parcialmente

O

Gostaria de investir em um clube

$\begin{array}{ccccc}\begin{array}{c}\text { Discordo } \\ \text { totalmente }\end{array} & \begin{array}{c}\text { Discordo } \\ \text { parcialmente }\end{array} & \begin{array}{c}\text { Não concordo, } \\ \text { nem discordo }\end{array} & \begin{array}{c}\text { Concordo } \\ \text { parcialmente }\end{array} & \begin{array}{c}\text { Concordo } \\ \text { totalmente }\end{array} \\ \bigcirc & \bigcirc & \bigcirc & \bigcirc & \bigcirc\end{array}$

Se meu time precisar, eu o ajudaria financeiramente.

$\begin{array}{ccccc}\begin{array}{c}\text { Discordo } \\ \text { totalmente }\end{array} & \begin{array}{c}\text { Discordo } \\ \text { parcialmente }\end{array} & \begin{array}{c}\text { Não concordo, } \\ \text { nem discordo }\end{array} & \begin{array}{c}\text { Concordo } \\ \text { parcialmente }\end{array} & \begin{array}{c}\text { Concordo } \\ \text { totalmente }\end{array} \\ \bigcirc & \bigcirc & \bigcirc & \bigcirc & \bigcirc\end{array}$

Acho que um clube, se transformando em uma empresa, passa a ter um potencial maior para investir, brigar por títulos etc.

Discordo

totalmente
Não concordo, nem discordo
Concordo parcialmente
Concordo totalmente parcialmente

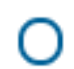

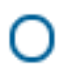


Sou a favor da transformação dos clubes em empresas.

$\begin{array}{ccccc}\text { Discordo } & \begin{array}{c}\text { Discordo } \\ \text { parcialmente }\end{array} & \begin{array}{c}\text { Não concordo, } \\ \text { nem discordo }\end{array} & \begin{array}{c}\text { Concordo } \\ \text { parcialmente }\end{array} & \begin{array}{c}\text { Concordo } \\ \text { totalmente }\end{array} \\ \bigcirc & \bigcirc & 0 & O & \bigcirc\end{array}$

Sou a favor da transformação dos clubes em empresas mesmo que haja mudanças na identidade do clube (escudo, bandeira, uniforme, cores, hino etc.).

$\begin{array}{ccccc}\text { Discordo } & \begin{array}{c}\text { Discordo } \\ \text { parcialmente }\end{array} & \begin{array}{c}\text { Não concordo, } \\ \text { nem discordo }\end{array} & \begin{array}{c}\text { Concordo } \\ \text { parcialmente }\end{array} & \begin{array}{c}\text { Concordo } \\ \text { totalmente }\end{array} \\ \bigcirc & \bigcirc & 0 & O & \bigcirc\end{array}$

Se, na transformação do clube em empresa, sua identidade (escudo, bandeira, uniforme, cores, hino etc.) for alterada, deixo de torcer para ele.

$\begin{array}{ccccc}\begin{array}{c}\text { Discordo } \\ \text { totalmente }\end{array} & \begin{array}{c}\text { Discordo } \\ \text { parcialmente }\end{array} & \begin{array}{c}\text { Não concordo, } \\ \text { nem discordo }\end{array} & \begin{array}{c}\text { Concordo } \\ \text { parcialmente }\end{array} & \begin{array}{r}\text { Concordo } \\ \text { totalmente }\end{array} \\ \bigcirc & \bigcirc & 0 & \bigcirc & \bigcirc\end{array}$

Classifique os tópicos dos que mais te agradam para os que menos te agradam em relação aos clube-empresas, sendo 1 o que mais lhe agrada e 5 o que menos.

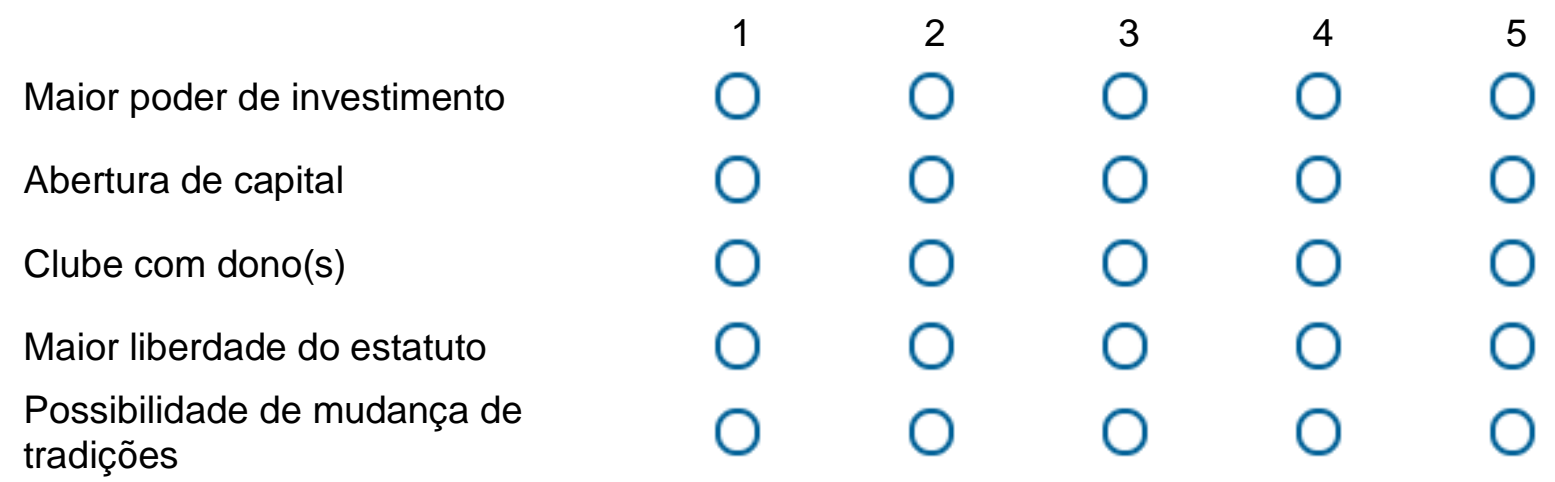


Marque as opções que se aplicam ao seu comportamento em relação ao seu clube.

$\square$ Me esforço para ver os jogos

$\square$ Gosto de ir ao estádio

$\square$ Possuo uniforme do meu time

$\square$ Possuo produtos do meu time (tirando uniforme)

Acompanho notícias do clube

Acompanho o clube nas redes sociais

Sou sócio do clube

Sou membro de torcida organizada

\section{Perfil do respondente.}

Estamos quase no final! Peço apenas que responda mais algumas perguntas sobre você. Desde já, agradeço.

Time

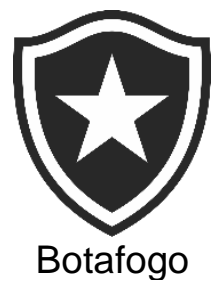

0

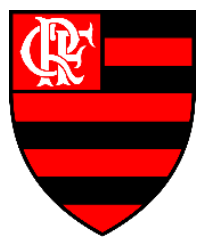

Flamengo

0

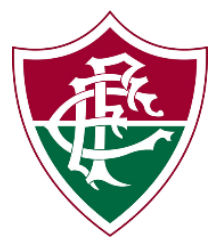

Fluminense

0

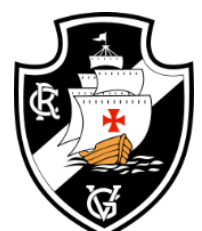

Vasco da Gama

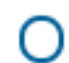

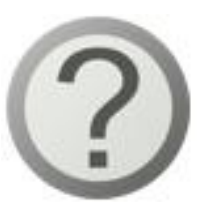

Outro 
Idade

Menos de 18 anos

Entre 18 e 24 anos

Entre 25 e 31 anos

Entre 32 e 38 anos

Entre 39 e 45 anos

Entre 46 e 52 anos

Mais que 52 anos

Gênero
Masculino
Feminino

Grau de escolaridade
Ensino médio incompleto/cursando
Ensino médio completo
Ensino superior incompleto/cursando
Ensino superior completo
Pós-graduação incompleta/cursando
Pós-graduação completa 
Renda familiar

Até $\mathrm{R} \$ 1.996,00$

De $R \$ 1.996,01$ a $R \$ 3.992,00$

De $R \$ 3.992,01$ a $R \$ 9.980,00$

De $R \$ 9.980,01$ a $R \$ 19.960,00$

$\mathrm{R} \$ 19.960,01$ ou mais 